\title{
A systematic review of the overlap of fluid biomarkers in delirium and advanced cancer-related syndromes
}

\author{
Ingrid Amgarth-Duff ${ }^{*}$, Annmarie Hosie ${ }^{1}$, Gideon Caplan ${ }^{2,3}$ and Meera Agar 1,4,5
}

\begin{abstract}
Background: Delirium is a serious and distressing neurocognitive disorder of physiological aetiology that is common in advanced cancer. Understanding of delirium pathophysiology is largely hypothetical, with some evidence for involvement of inflammatory systems, neurotransmitter alterations and glucose metabolism. To date, there has been limited empirical consideration of the distinction between delirium pathophysiology and that of the underlying disease, for example, cancer where these mechanisms are also common in advanced cancer syndromes such as pain and fatigue. This systematic review explores biomarker overlap in delirium, specific advanced cancerrelated syndromes and prediction of cancer prognosis.

Methods: A systematic review (PROSPERO CRD42017068662) was conducted, using MEDLINE, PubMed, Embase, CINAHL, CENTRAL and Web of Science, to identify body fluid biomarkers in delirium, cancer prognosis and advanced cancer-related syndromes of interest. Studies were excluded if they reported delirium tremens only; did not measure delirium using a validated tool; the sample had less than $75 \%$ of participants with advanced cancer; measured tissue, genetic or animal biomarkers, or were conducted post-mortem. Articles were screened for inclusion independently by two authors, and data extraction and an in-depth quality assessment conducted by one author, and checked by two others.

Results: The 151 included studies were conducted in diverse settings in 32 countries between 1985 and 2017, involving 28130 participants with a mean age of 69.3 years. Seventy-one studies investigated delirium biomarkers, and 80 studies investigated biomarkers of an advanced cancer-related syndrome or cancer prognosis. Overall, 41 biomarkers were studied in relation to both delirium and either an advanced cancer-related syndrome or prognosis; and of these, 24 biomarkers were positively associated with either delirium or advanced cancer syndromes/ prognosis in at least one study. The quality assessment showed large inconsistency in reporting.

Conclusion: There is considerable overlap in the biomarkers in delirium and advanced cancer-related syndromes. Improving the design of delirium biomarker studies and considering appropriate comparator/controls will help to better understanding the discrete pathophysiology of delirium in the context of co-existing illness.
\end{abstract}

Keywords: Delirium, Biomarker, Advanced cancer, Review

\footnotetext{
* Correspondence: Ingrid.Amgarth-Duff@uts.edu.au

'University of Technology Sydney, Faculty of Health, IMPACCT -Improving

Palliative, Aged and Chronic Care through Clinical Research and Translation, Sydney, NSW, Australia

Full list of author information is available at the end of the article
}

(C) The Author(s). 2020 Open Access This article is licensed under a Creative Commons Attribution 4.0 International License, which permits use, sharing, adaptation, distribution and reproduction in any medium or format, as long as you give appropriate credit to the original author(s) and the source, provide a link to the Creative Commons licence, and indicate if changes were made. The images or other third party material in this article are included in the article's Creative Commons licence, unless indicated otherwise in a credit line to the material. If material is not included in the article's Creative Commons licence and your intended use is not permitted by statutory regulation or exceeds the permitted use, you will need to obtain permission directly from the copyright holder. To view a copy of this licence, visit http://creativecommons.org/licenses/by/4.0/ The Creative Commons Public Domain Dedication waiver (http://creativecommons.org/publicdomain/zero/1.0/) applies to the data made available in this article, unless otherwise stated in a credit line to the data. 


\section{Background}

Delirium is a very common cause of acute cognitive change in people with advanced cancer [1] and is associated with increased morbidity and mortality [2, 3]. Delirium is a serious and complex neurocognitive disorder characterized by acute deterioration in attention, awareness and cognition, variously affecting memory, language and visuospatial ability, orientation and perception [4].

Delirium occurs in people who are medically unwell, due to the underlying disease which has put them at risk (e.g. dementia, cancer, infection, renal impairment) or intercurrent problems, and the subsequent medical treatment (e.g. surgery, medication). Delirium can occur for any person, with those who are older, have advanced illness, and/or prior cognitive impairment most at risk [5]. The prevalence of delirium in patients with advanced cancer in oncology and palliative care settings is higher than that in most other settings, including geriatrics $[1,6-9]$. A systematic review of palliative care patients (with $98.9 \%$ of participants with advanced cancer), reported delirium incidence rates between $3 \%$ and $45 \%$. Delirium prevalence ranged from $13.3 \%$ to $42.3 \%$ at admission to hospital, and $25 \%$ to $62 \%$ during admission. Delirium prevalence increased up to $88 \%$ in the hours to days before death [1].

The pathophysiology of delirium is poorly understood, and largely hypothetical. Current hypotheses include: neuronal ageing, neuroinflammation, oxidative stress, neuroendocrine dysregulation, disruption to the circadian rhythm, and neurotransmitter dysregulation [10, 11]. A reduction in glucose metabolism seen in people with delirium is a model with developing evidence [12, 13]. Collectively, the biological correlates of delirium are referred to as 'delirium biomarkers'. A biomarker is a biological molecule found in blood, other body fluids, or tissues that is a sign of a normal or abnormal process, or of a condition or disease [14]. Biomarkers are most commonly studied to investigate their correlation with a disease in order to better understand its underlying pathophysiology, and subsequently inform prevention and treatment strategies for that disease. A challenge for the field of delirium research is that correlation may exist between biomarkers of delirium and those of the patient's disease or injury which placed them at increased risk of delirium, or which precipitated it (for example sepsis or hip fracture). Such correlation should be factored into delirium biomarker research, yet rarely has been. Better understanding of the interplay between delirium pathophysiology and that of correlated conditions and diseases, for example, cancer (the focus of this review), is crucial to develop more effective prevention and treatment of delirium.

We therefore conducted a systematic review of the literature to explore the overlap between biomarkers that have been studied in delirium and biomarkers that have been studied in cancer-related syndromes. Our aim was to identify biomarkers associated with delirium and with specific clinical situations in advanced cancer (namely prognosis; cognitive impairment, anorexia cachexia, cancer pain, cancer-related fatigue, and sickness behavior); and to evaluate the nature and extent of overlap of the findings.

\section{Methods}

A systematic review according to the Preferred Reporting Items for Systematic Reviews and Meta-Analyses (PRISMA) [15] was conducted. In July 2017, two separate searches were conducted in MEDLINE, PubMed, Embase, CINAHL, CENTRAL, and Web of Science. The first was for literature of delirium biomarkers; the second was for literature of biomarkers in advanced cancer-related syndromes. Primary terms for the delirium search were: 'delirium' and 'biomarker'. Search terms for the cancer search were: 'cancer', 'neoplasms', 'metastasis', 'fatigue', 'sickness behavior', 'cancer pain', 'cachexia', and 'prognosis'. Additional terms which encompassed commonly researched biomarkers were also included. Filters in Medline were: 1: Humans; 2. English language and 3. Published from 1980 onward (when delirium was first included in the DSM, Third Edition (DSM-III)). Search terms and filters were tailored to each subsequent database, as required. The full search strategy is provided in Additional file 1 . Reference lists of included studies and relevant systematic reviews and meta-analyses identified in the search were examined for additional eligible studies.

We included English language studies published in peer-reviewed journals that reported body fluid biomarkers in adult participants with delirium, cancer prognosis or an advanced cancer-related syndrome of interest. Studies were excluded if they reported delirium tremens only; did not measure delirium using a validated tool; the sample had less than $75 \%$ of participants with advanced cancer; measured tissue, genetic or animal biomarkers, or were conducted post-mortem. Protocols and ongoing studies were also excluded. Based on the expert knowledge of the authors in both delirium and cancer, the advanced cancer-related syndromes and prognosis were chosen based on the potential biological plausibility that the pathophysiological mechanisms could overlap with that of delirium. We limited the search to advanced cancer as this is the cancer population with the highest prevalence of both delirium and the cancer-related syndromes of interest.

The following definitions were used in this review:

Anorexia cachexia: A complex metabolic syndrome of involuntary weight loss associated with cancer and some other palliative conditions [16]. 
Cancer related fatigue: A distressing, persistent, subjective sense of physical, emotional, and/or cognitive tiredness or exhaustion related to cancer and/or cancer treatment that is not proportional to recent activity and interferes with usual functioning [17].

Cancer-related pain: An unpleasant sensory and emotional experience associated with actual or potential tissue damage, or described in terms of such damage [18].

\section{Cancer-related cognitive impairment: Cognitive} impairment that is commonly experienced by cancer patients and those in remission. The cognitive domains most commonly affected are memory, concentration, information processing speed and executive function [19].

Sickness behaviour: The coordinated set of behavioural changes that develop in sick individuals during the course of an infection. Sickness behavior is also seen in other illness including cancer [20, 21].

Cancer prognosis: The likely outcome or course of the disease; the chance of recovery or recurrence. Cancer prognosis is assessed by cancer-specific survival, overall survival, progression free survival or relative survival [22].

Search results were imported into Endnote X7 software, duplicates removed and then exported into Covidence $^{\mathrm{TM}}$ (www.covidence.org). Two reviewers per search (IAD and AH: delirium search, IAD and MA: cancer search) independently applied eligibility criteria for both searches and examined title and abstracts. Exclusions were documented only for articles that required full-text to make a formal decision. Inter-reviewer disagreement on included studies was discussed to resolve any discrepancies, with the third reviewer consulted when required. Data extraction was conducted by one reviewer (IAD) using Excel (2016) with two other reviewers (MA and $\mathrm{AH})$ providing input and oversight. Data extraction was guided by the REporting recommendations for tumor MARKer prognostic studies (REMARK) checklist [23].

In the absence of a gold standard risk of bias assessment for biomarker studies, one reviewer (IAD) applied an adaptation of the REMARK checklist [23] to assess the methodological quality of the included studies, with $10 \%$ verification by two other reviewers (MA and $\mathrm{AH}$ ).

The heterogeneity of data precluded performing a meta-analysis; we therefore reported the data using a narrative synthesis approach with text and tabular summaries. The synthesis was structured according to the overlap of the biomarkers in delirium, cancer prognosis and the cancer syndromes, the biomarker type, assay used, and numbers and proportions of participants who had delirium and advanced cancer. We defined 'overlap' as any biomarker that was studied in both a delirium study and an advanced cancer syndrome study.

\section{Results}

The delirium search yielded 3342 articles and the cancer syndromes search 4081, giving a total of 7423 articles. An additional 25 articles were found through the hand search. After removal of 1817 duplicates and 5120 articles through title and abstract screening, we reviewed 511 full text papers and subsequently excluded 288 . After initial analysis, a further 72 were excluded as they did not report a biomarker studied in delirium and advanced cancer. This resulted in a total of 151 articles included in this review: 71 reported biomarkers studied in delirium, and 80 reported biomarkers studied in a cancer syndrome or prognosis (Figure 1).

The 151 studies were conducted between 1985 and 2017 in Europe $(n=86)$, Asia $(n=33)$, The Americas $(n=$ $27)$, Australia $(n=2)$, and multiple regions $(n=3)$. Studies were set in a large range of settings, with the most common in general hospital settings $(n=111 ; 73 \%)$. Thirtynine studies (26\%) did not report the setting. Sample sizes ranged from 7-2456, with relatively even numbers of male and female participants (55.4\% male). Ninety nine articles reported a mean age, with an overall weighted mean age of 69.3 years. Of the 37 articles that reported the median age of participants, the overall median age was 54.5 years. The overall age of participants in the remaining 15 articles was not possible to determine (Additional files 2 and 3). Blood biomarkers were examined in 138 studies, 4 studies examined biomarkers in cerebrospinal fluid (CSF), 3 in urine, and $16(11 \%)$ did not report the type of biological material. Of the studies that reported the assay technique, diverse assays were used $(n=20)$, with Enzyme-linked immunosorbent assay (ELISA) being the most common $(\mathrm{n}=62 ; 58 \%)$. Fortyfour studies (29\%) did not report the specific assay used. Of these, 21 studies (48\%) were routinely measured biomarkers (Tables 1 and 2).

A total of 41 biomarkers were found to be common in both delirium and advanced cancer syndrome studies. The five most commonly studied biomarkers were Creactive protein (CRP) $(n=79)$, interleukin (IL)-6 $(n=58)$, tumor necrosis factor alpha (TNF- $\alpha)(n=42)$ IL-10 $(n=$ $21)$ and IL-8 $(n=24)$. Of these, 24 biomarkers had a positive association with delirium, cancer prognosis or a cancer syndrome in at least one study. No cancer studies reported having any participants with delirium, and of the delirium studies, six reported participants with cancer. Figure 2 illustrates two main populations identified from this systematic review, with the centre showing the 'true overlap' defined as studies that included participants with both delirium and cancer ( $\mathrm{n}=6$ studies).

In two of these studies, all participants in the study had cancer; in another, $64.2 \%$ of participants had cancer; in the remaining three studies, less than $30 \%$ of all participants had cancer. In three of the studies, $100 \%$ of 


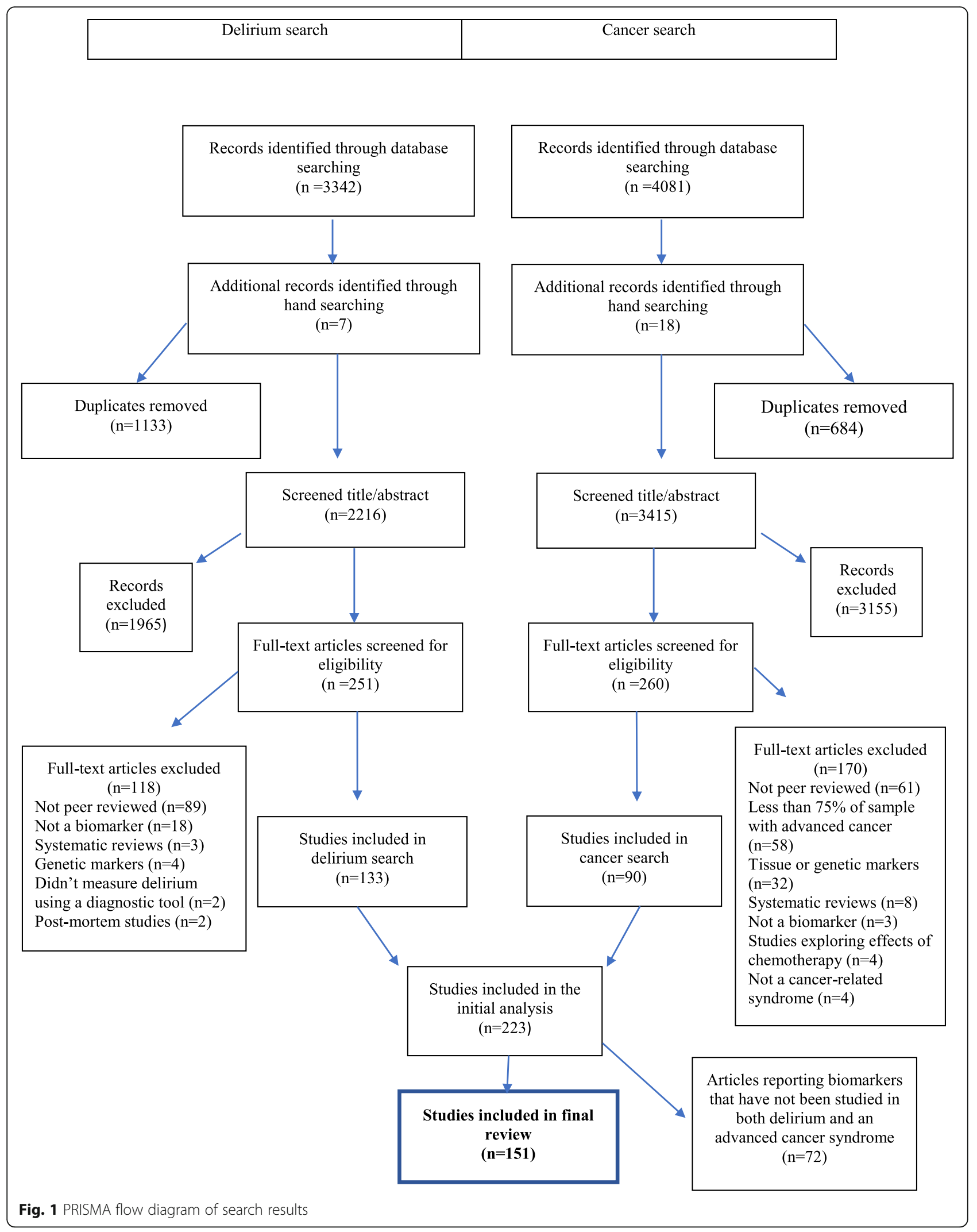




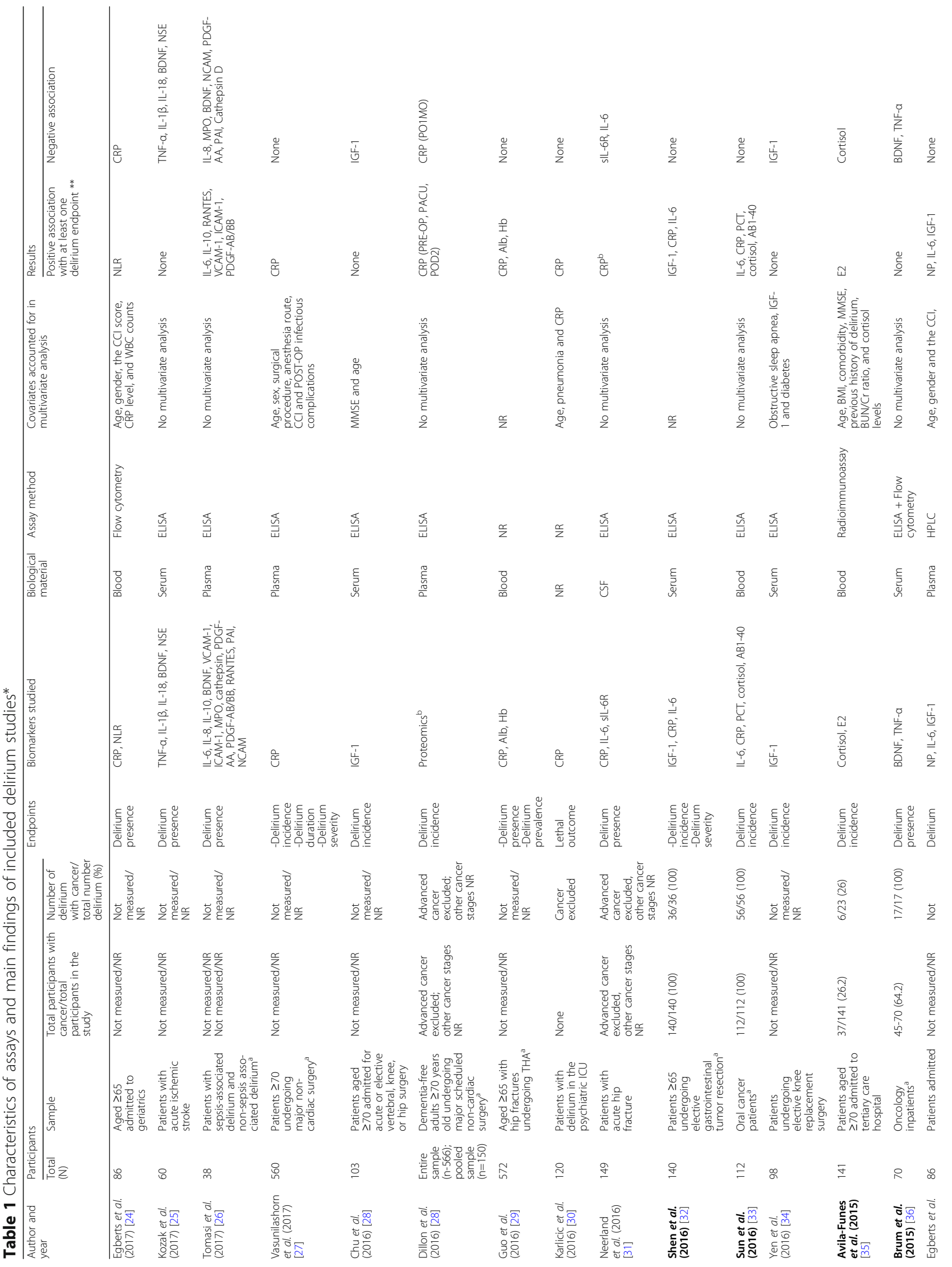




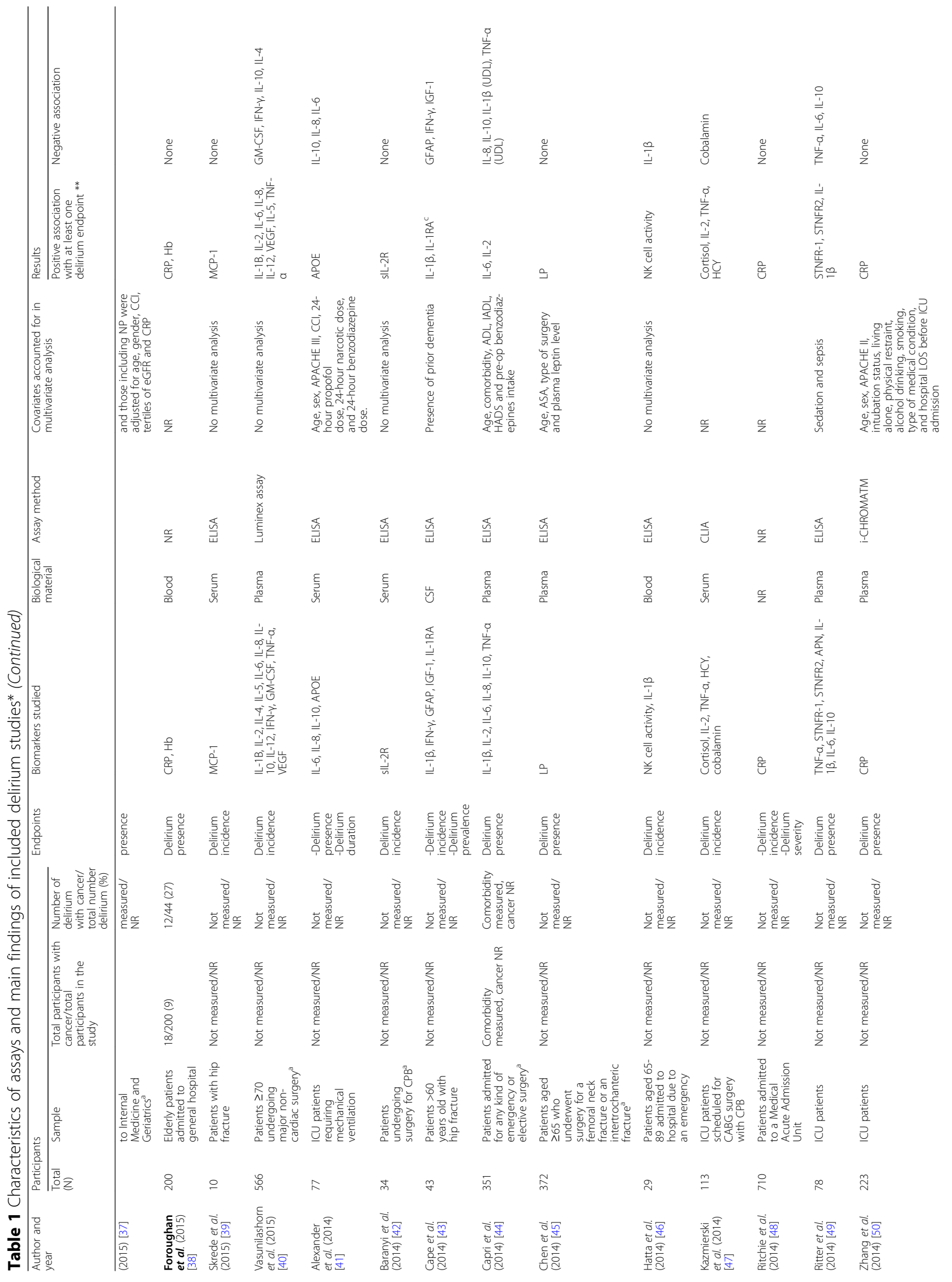




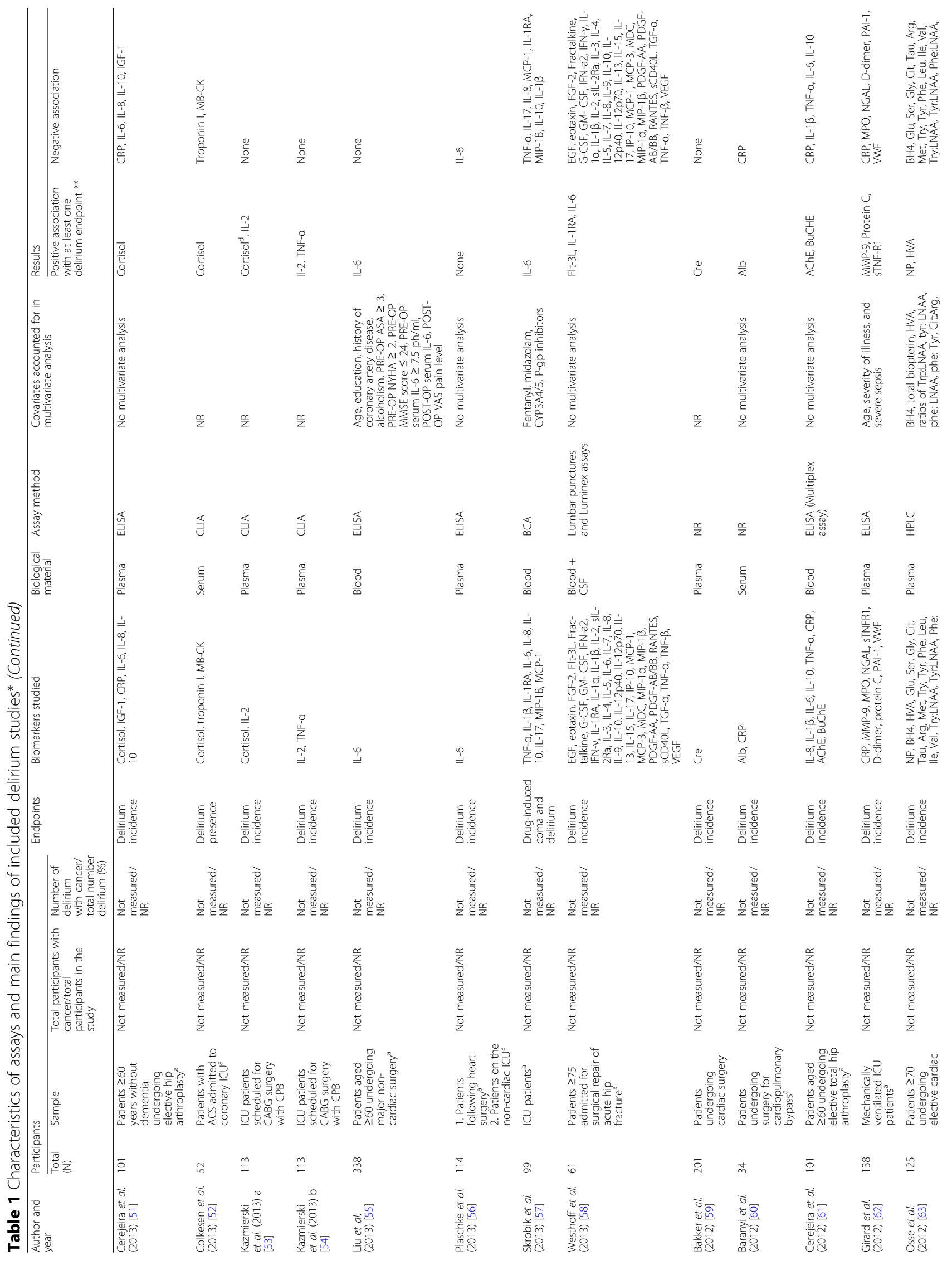




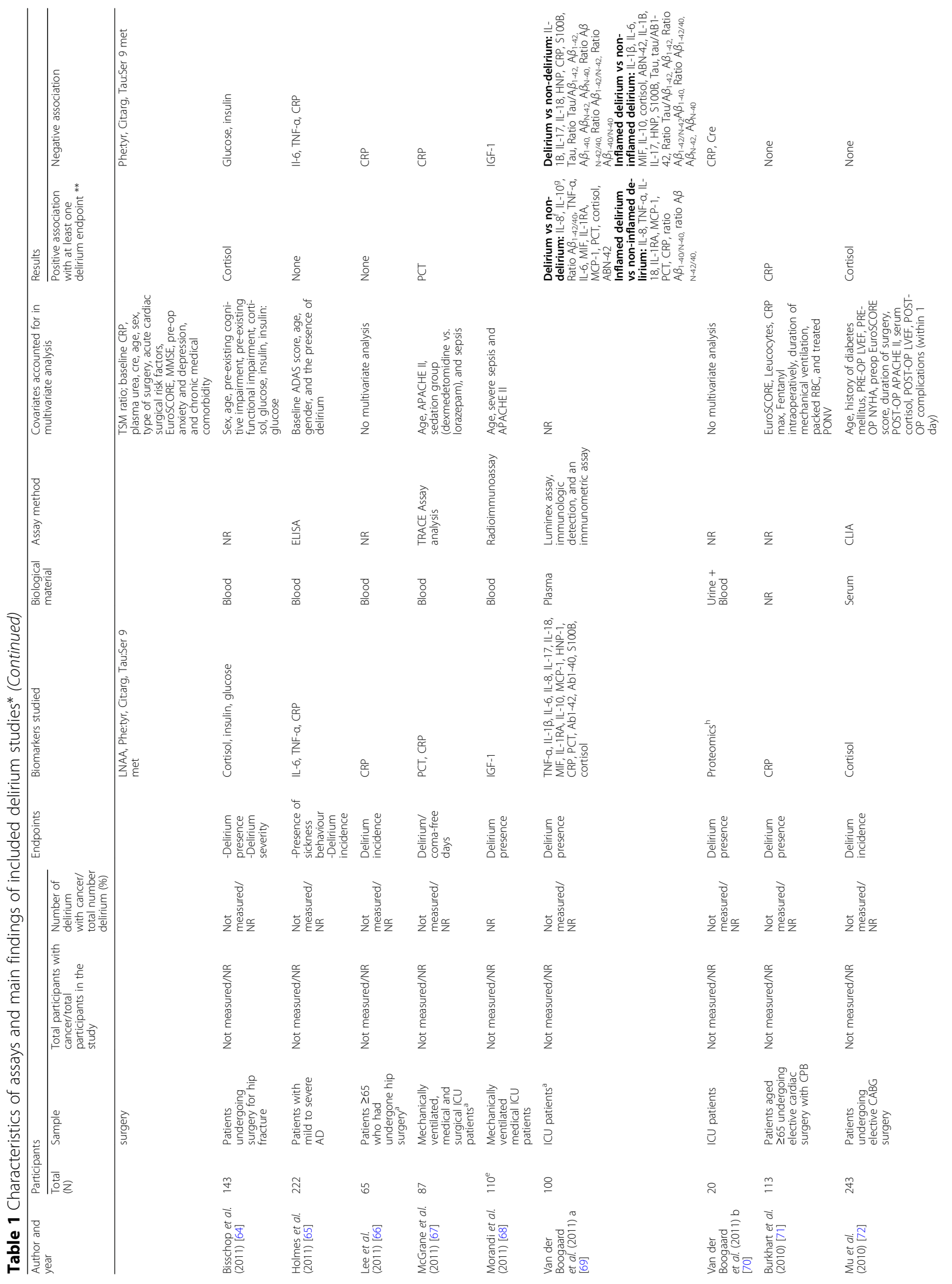




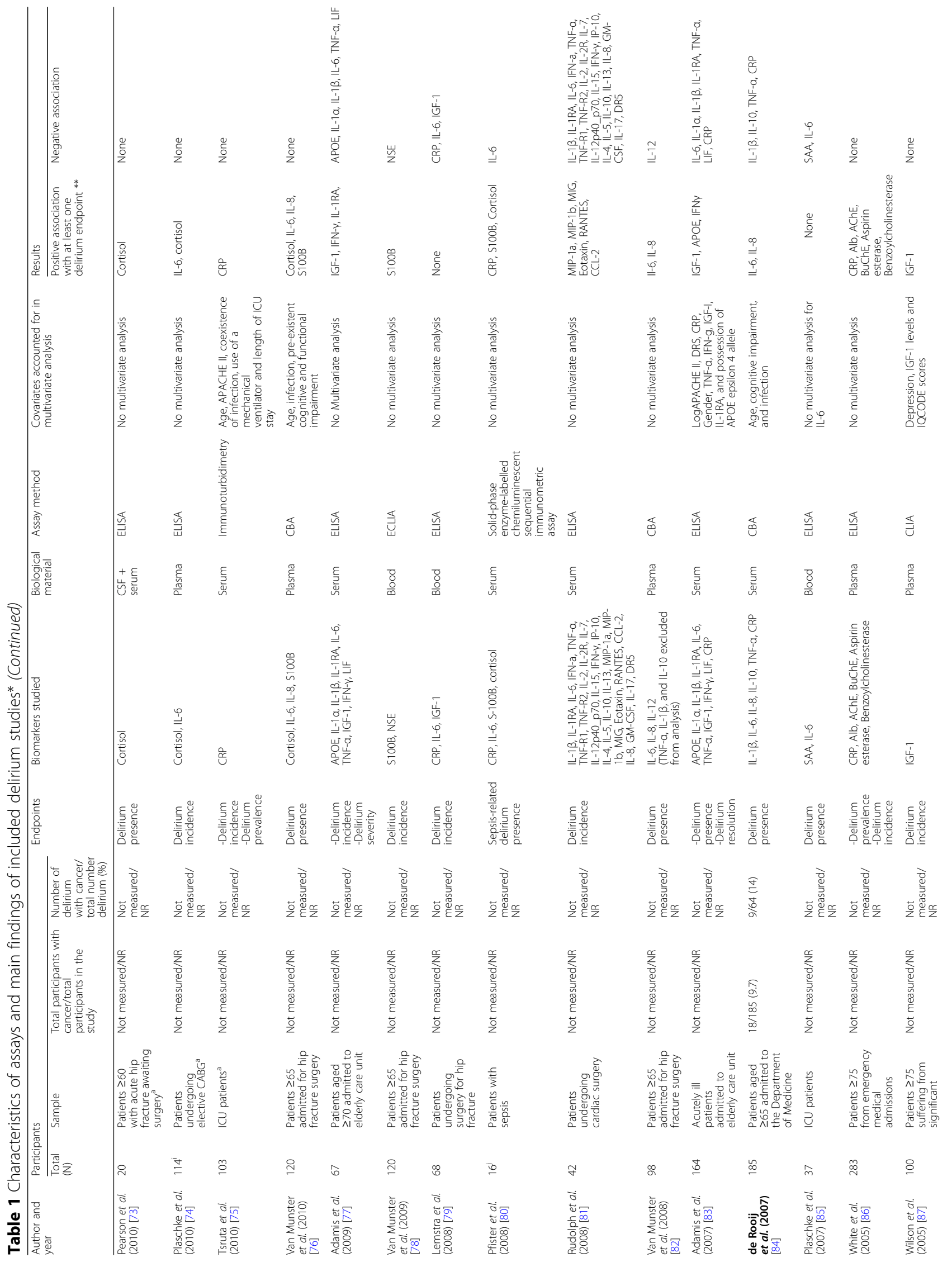




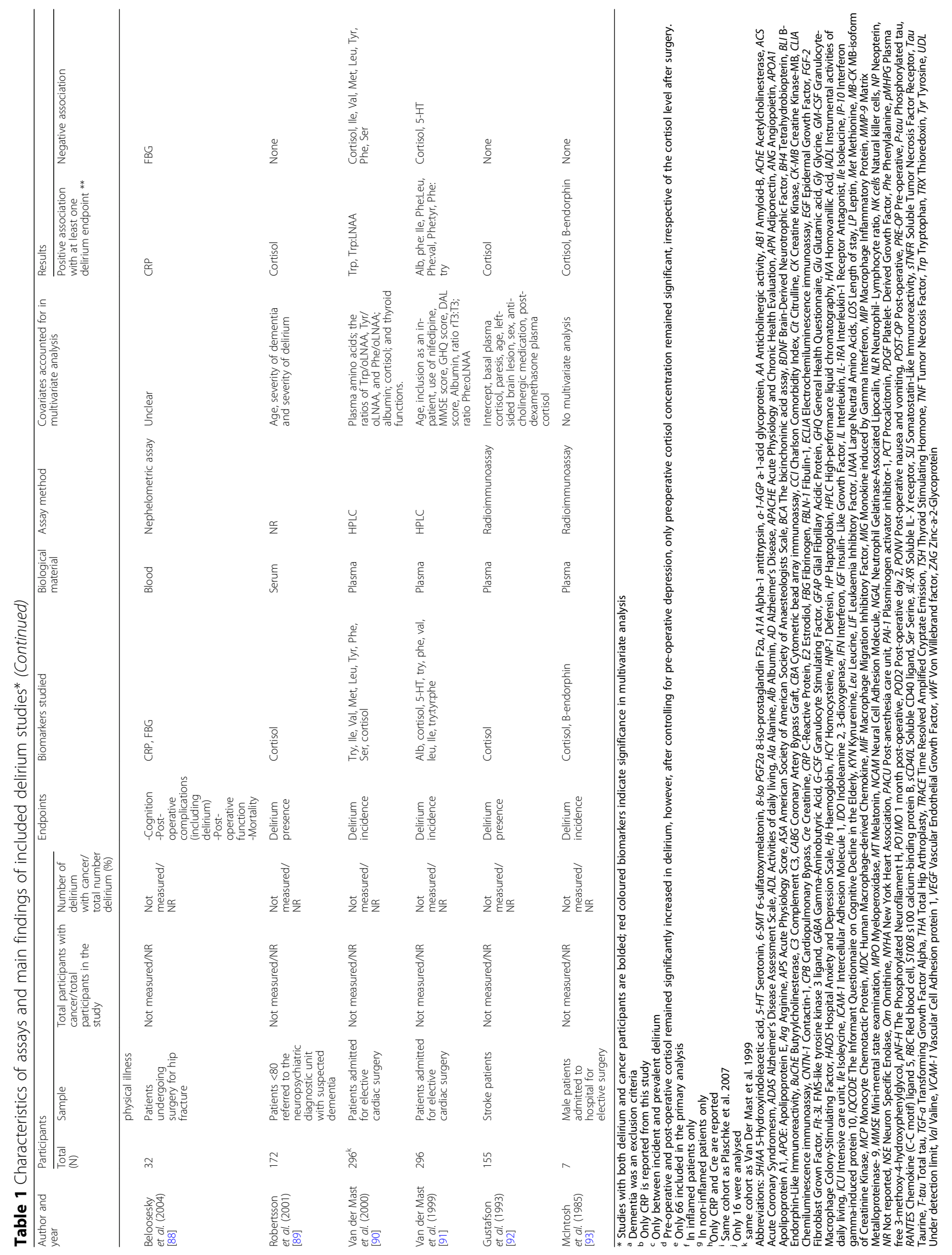




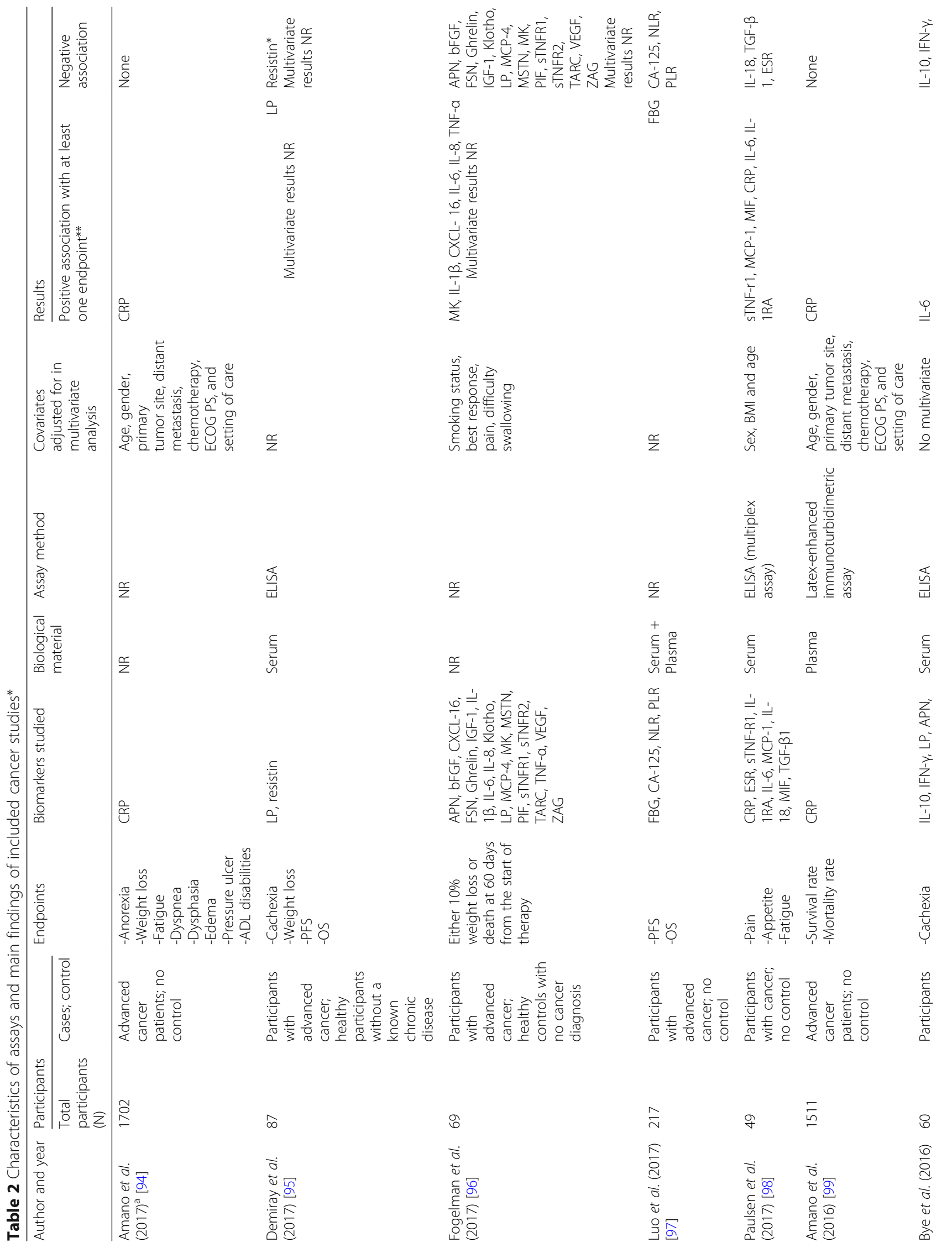




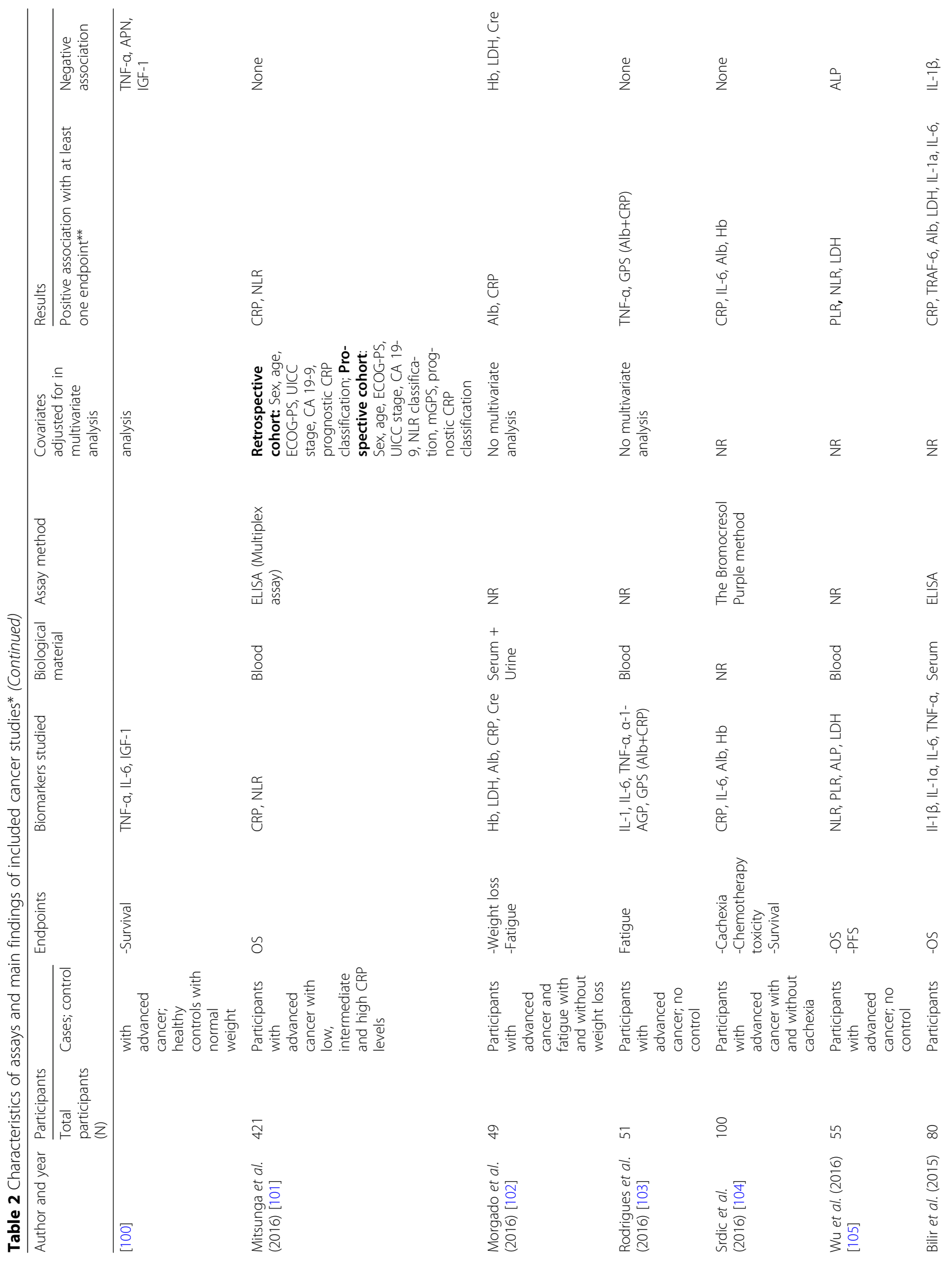




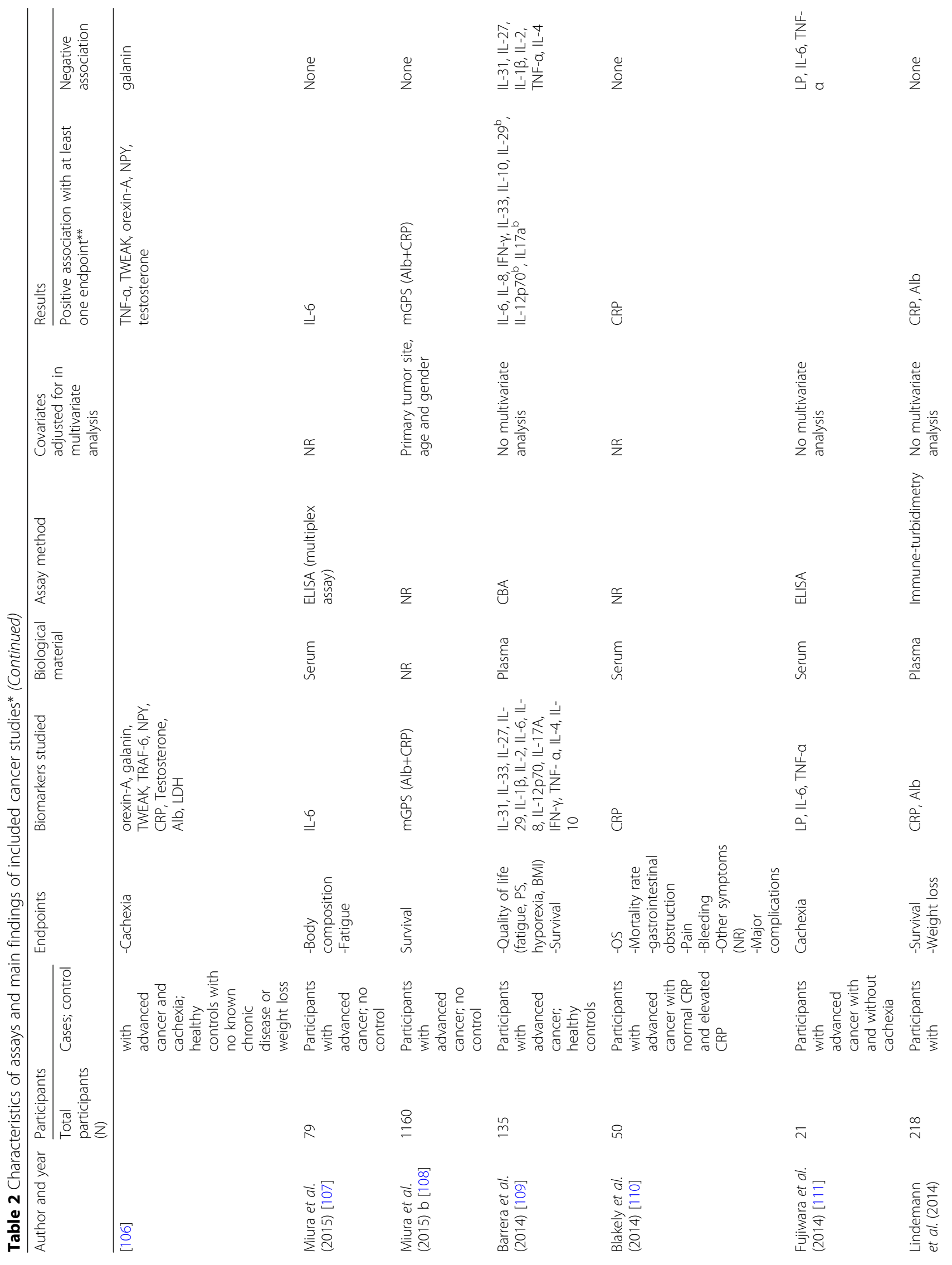




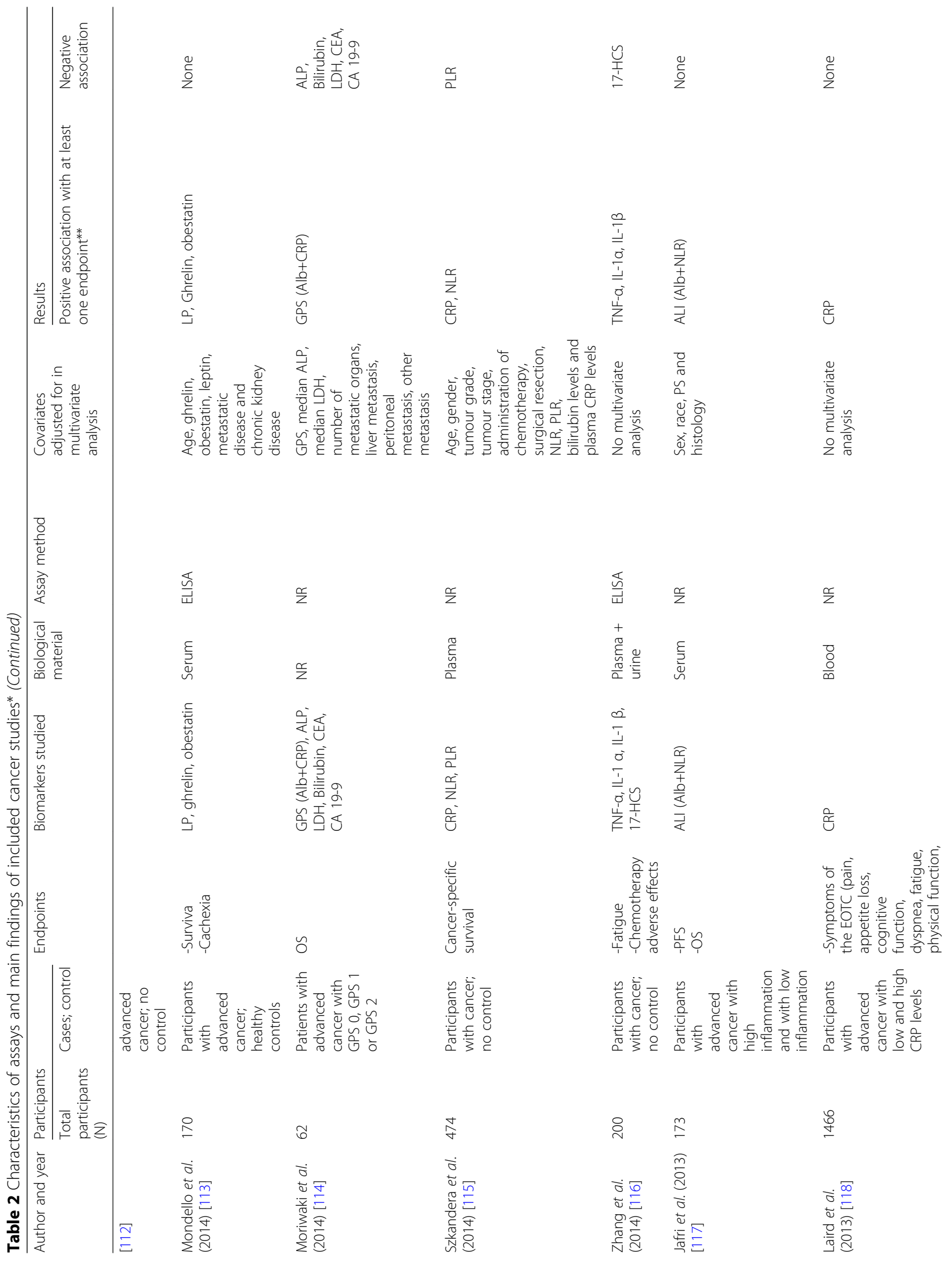




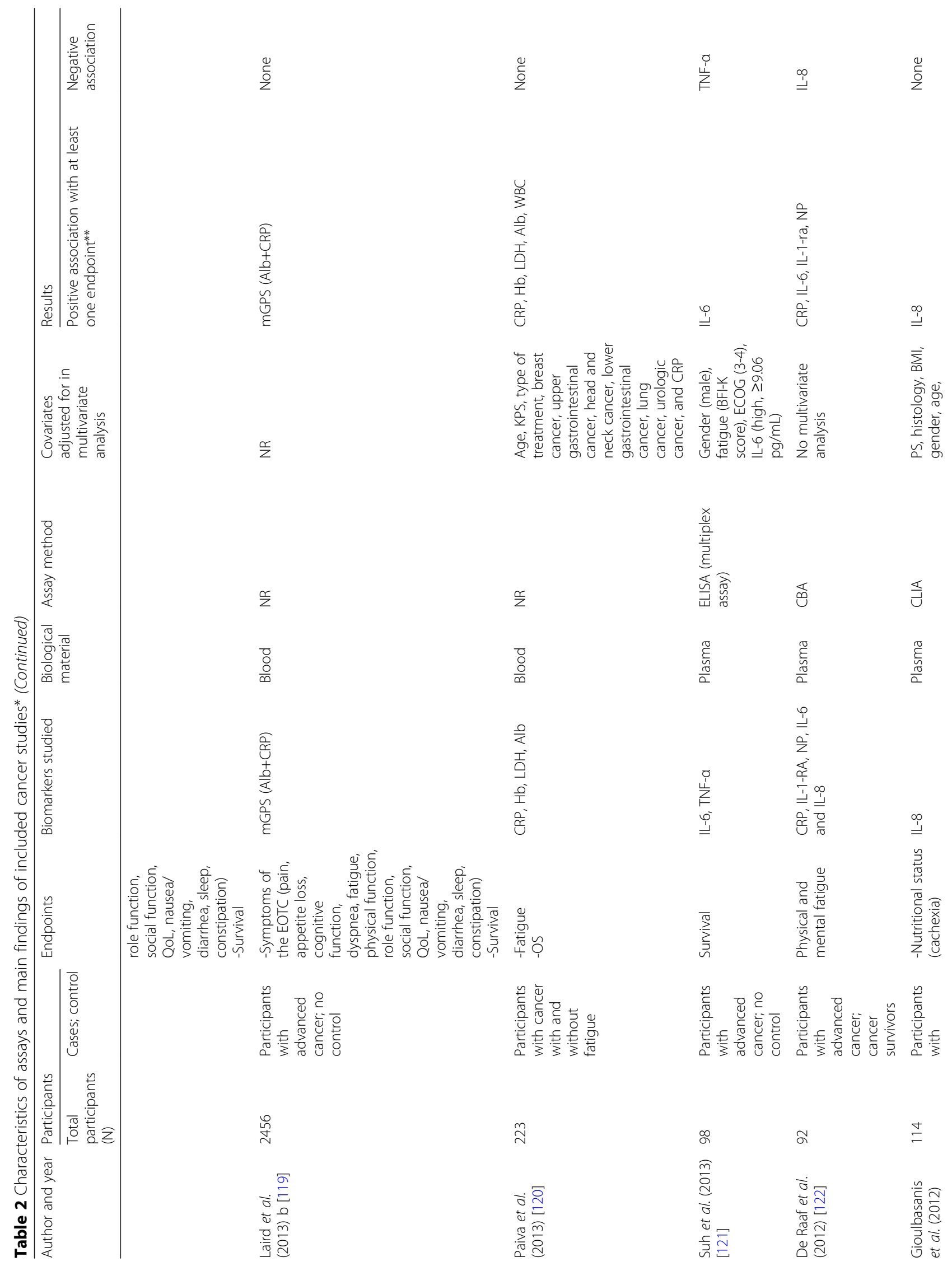




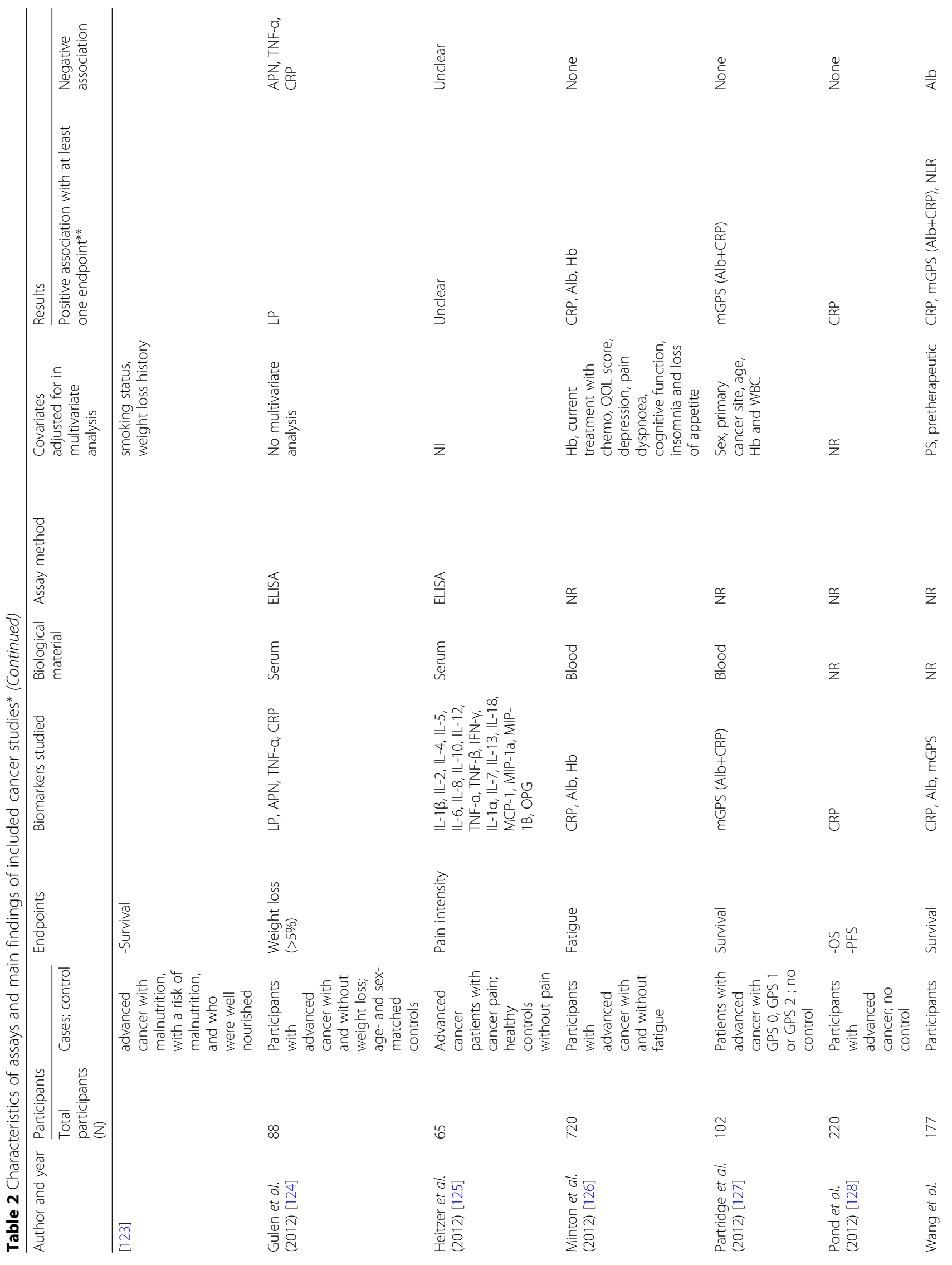




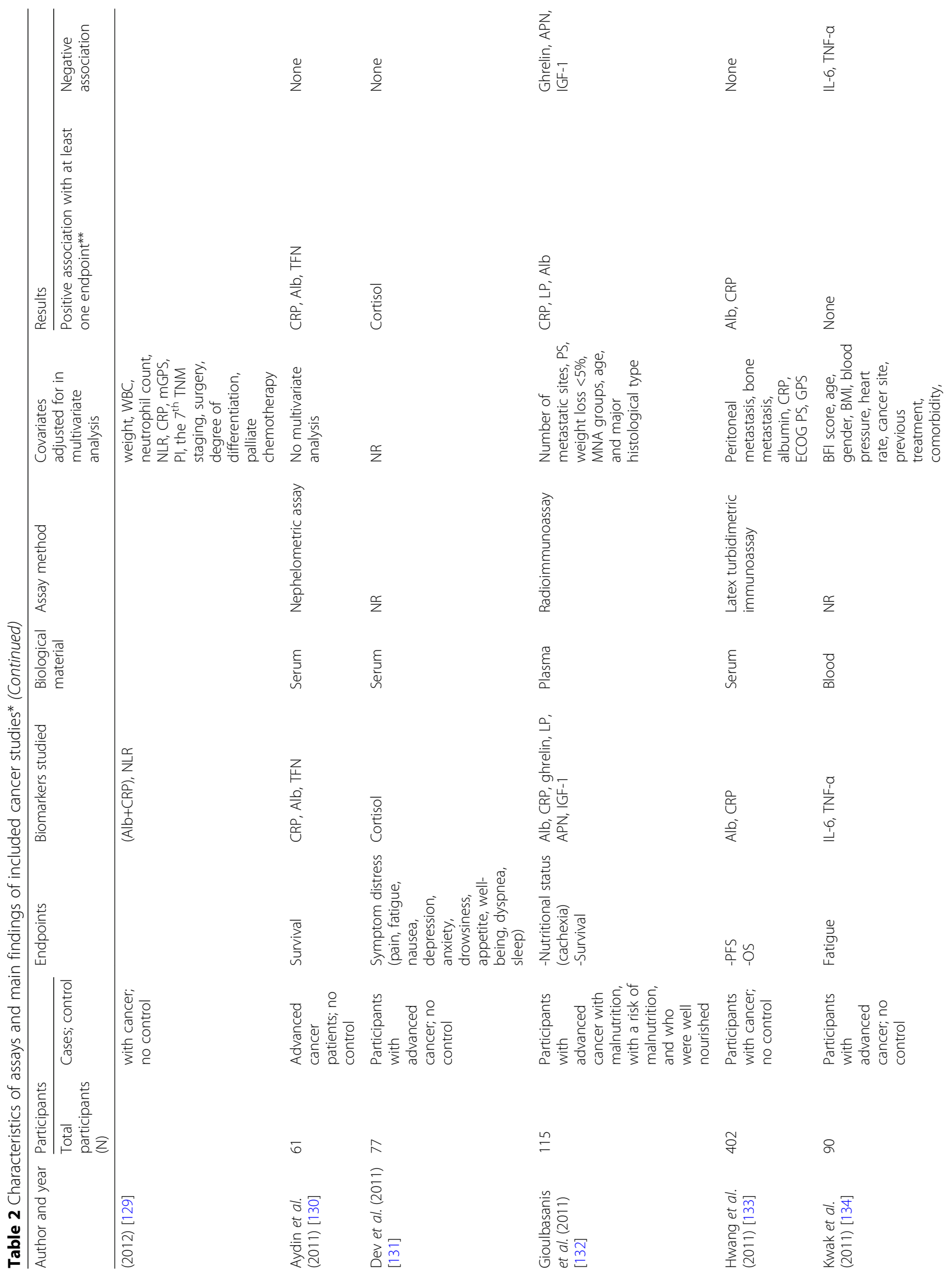




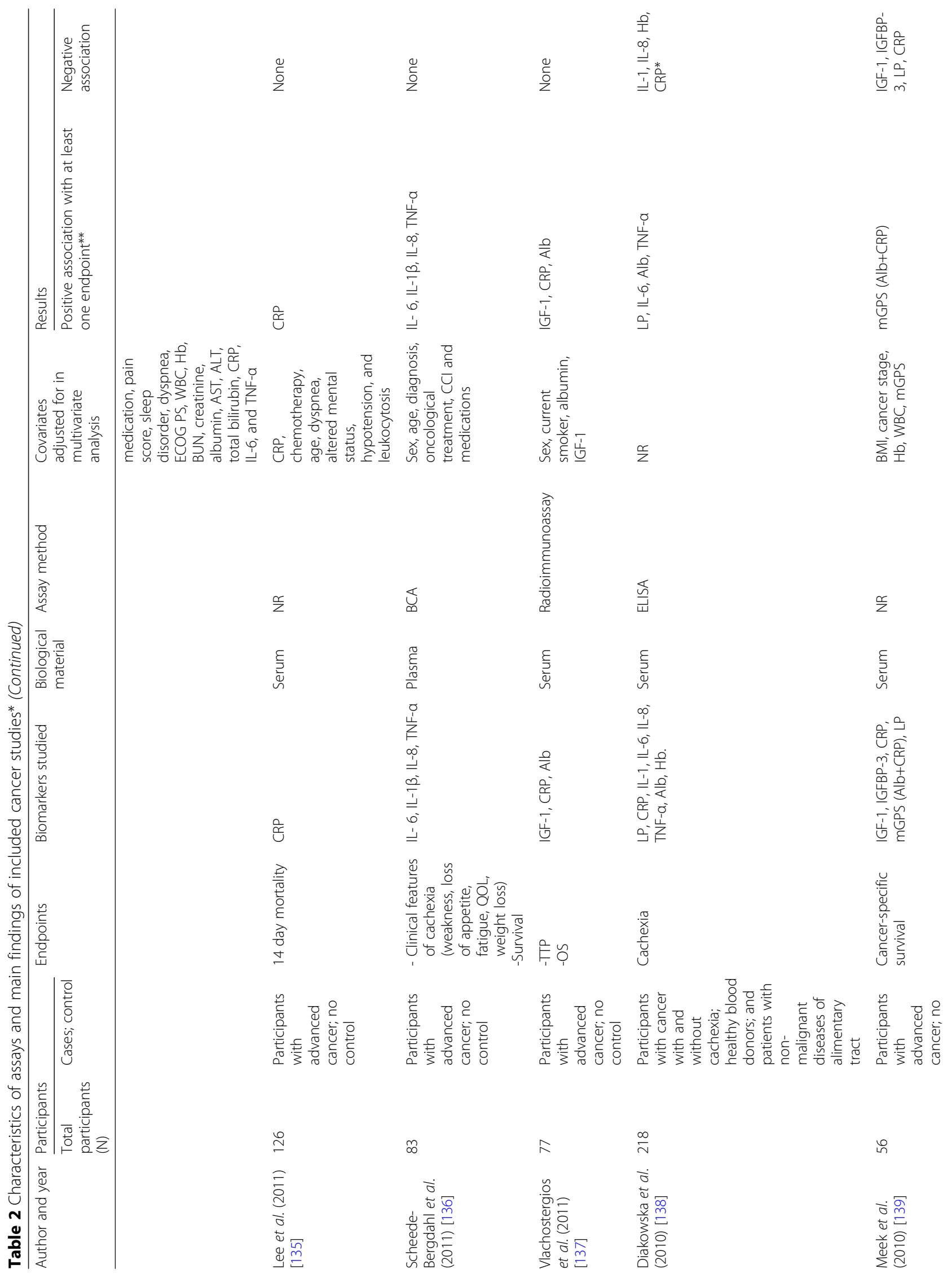




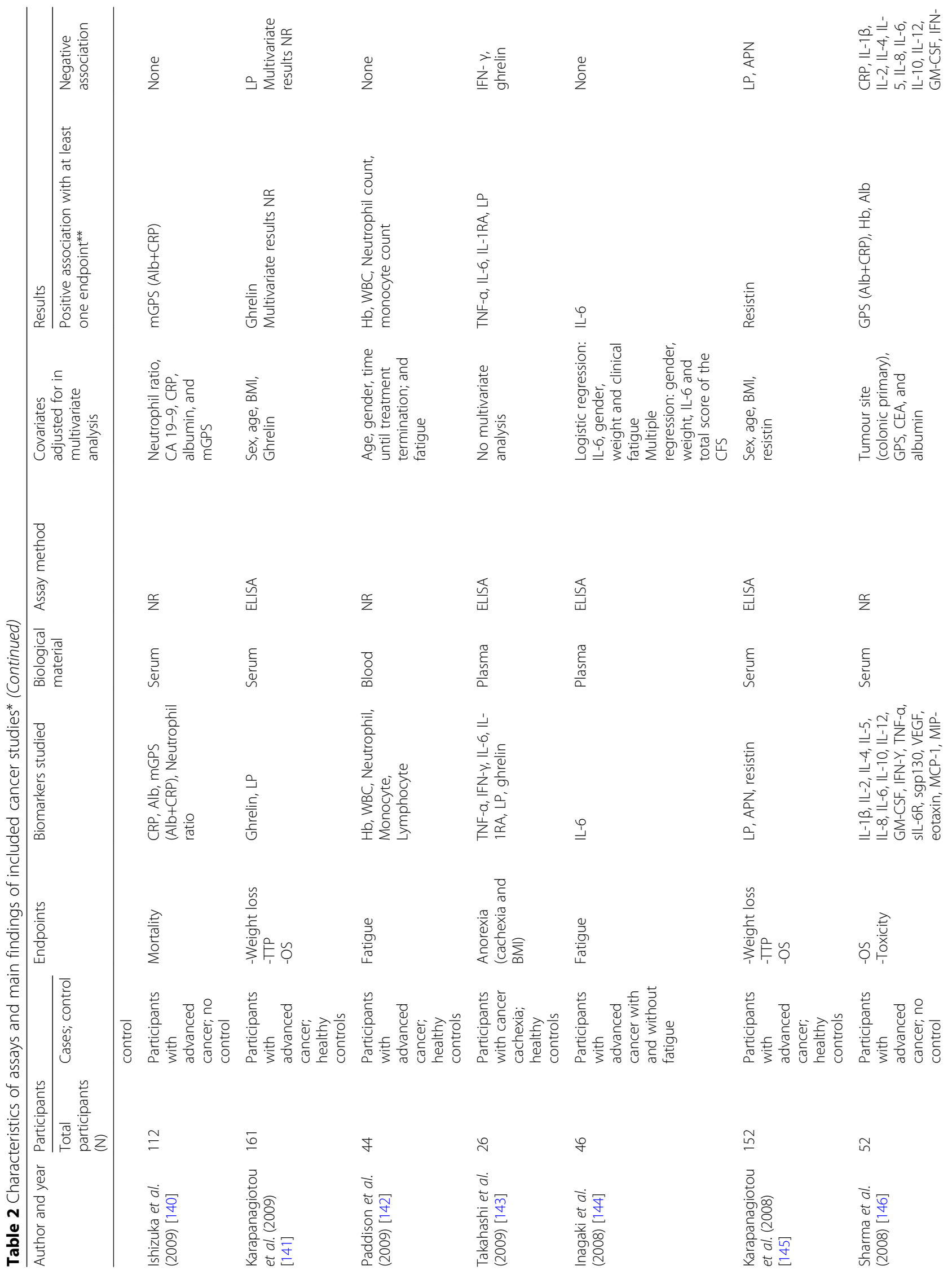




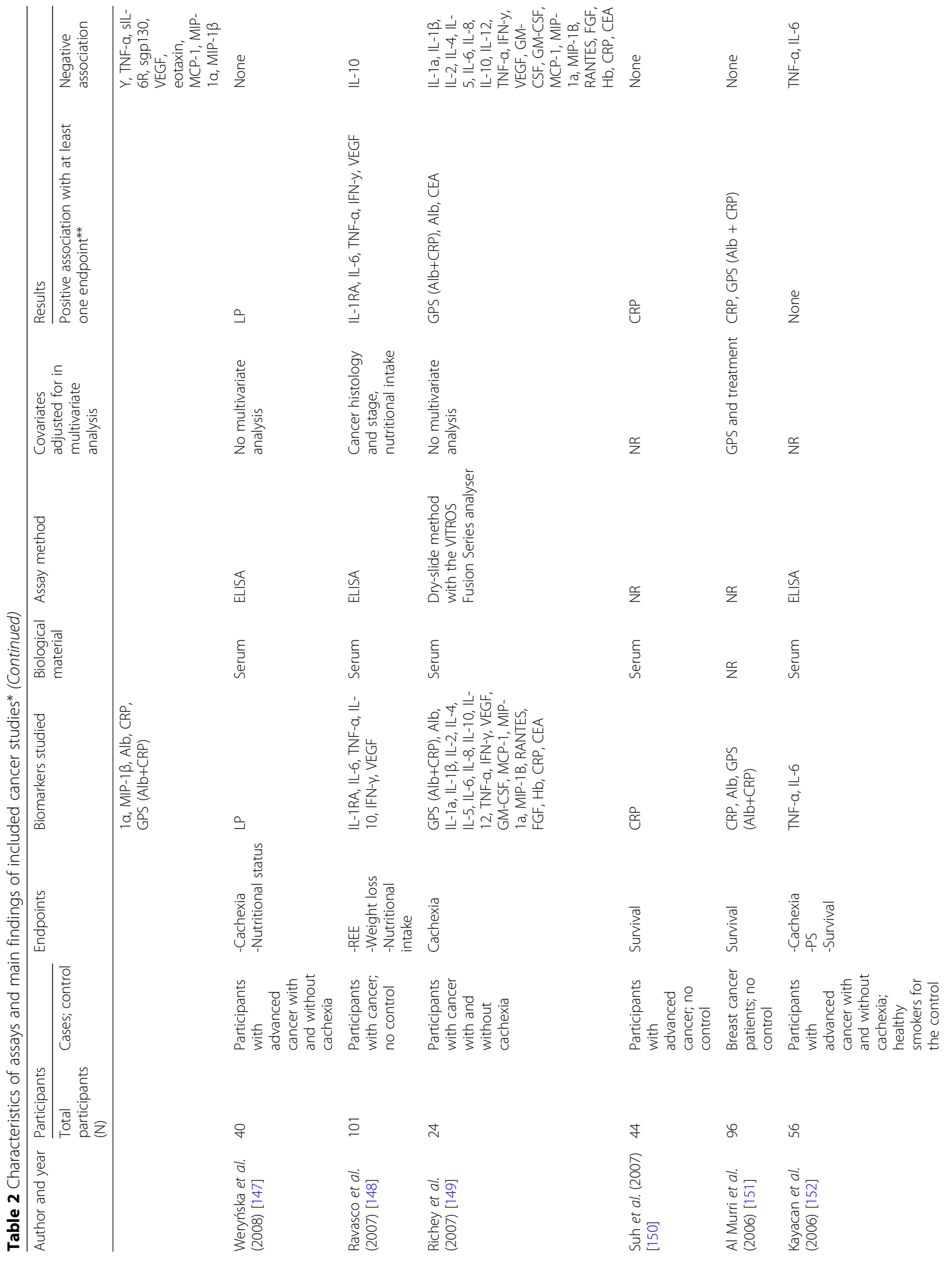




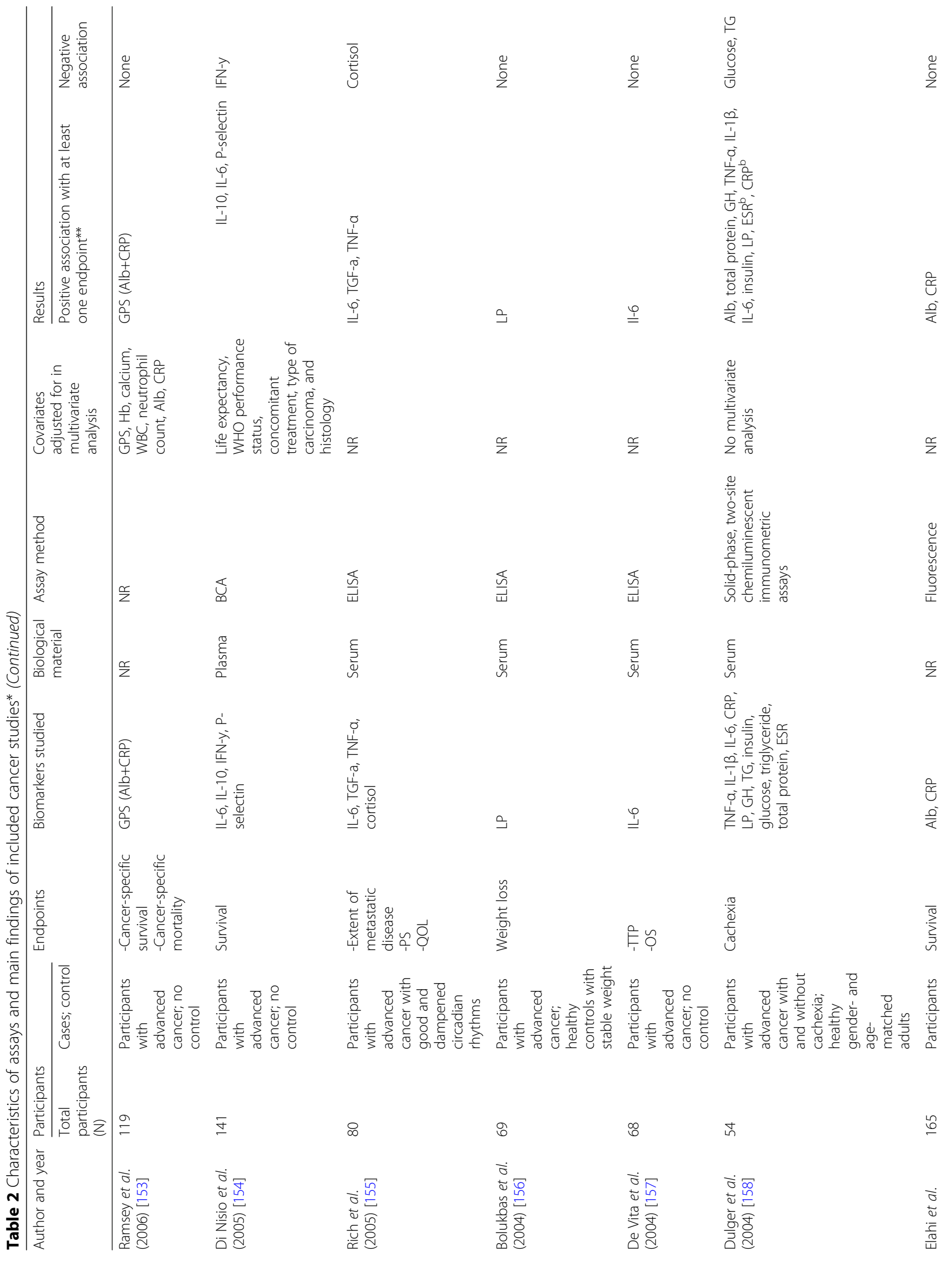




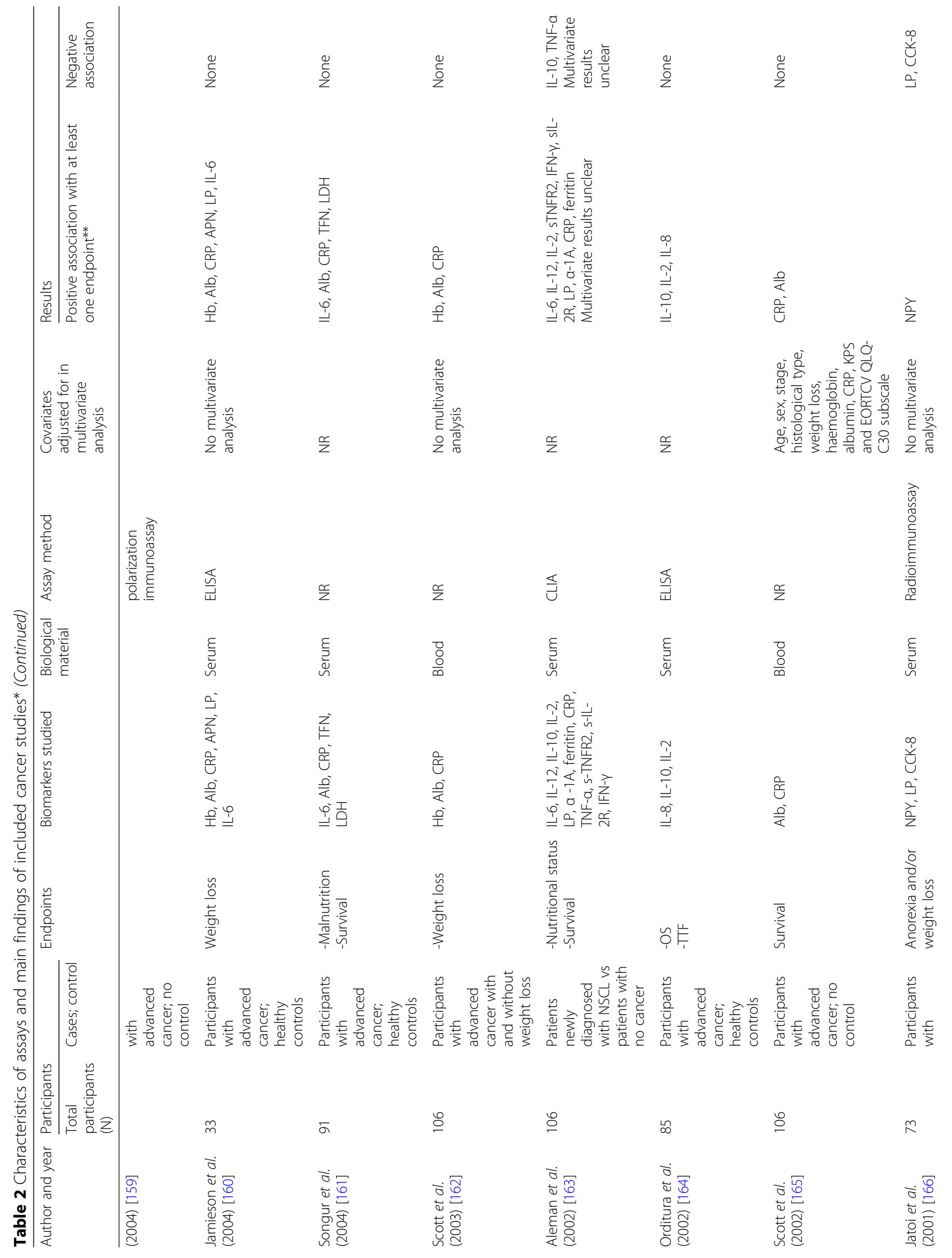




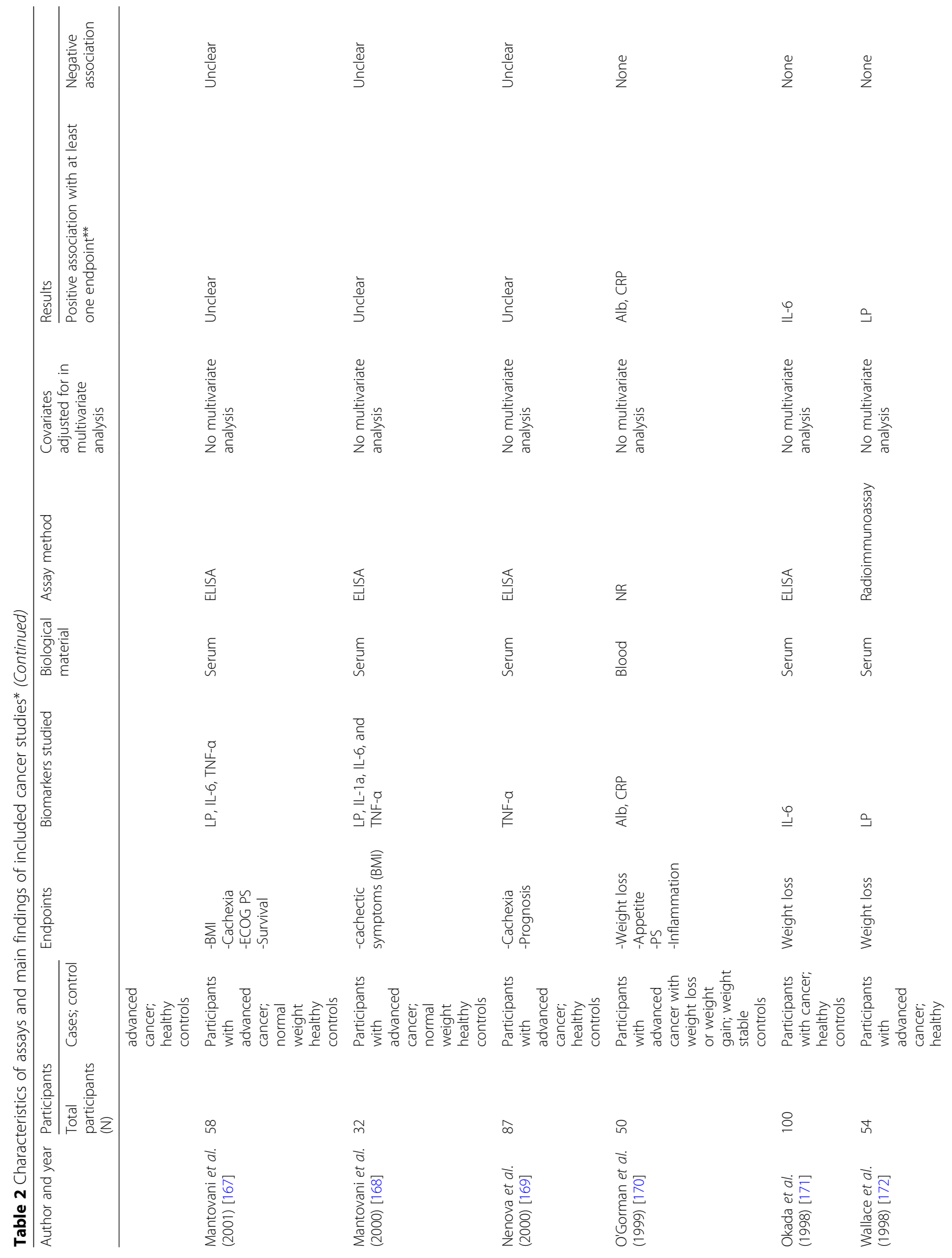




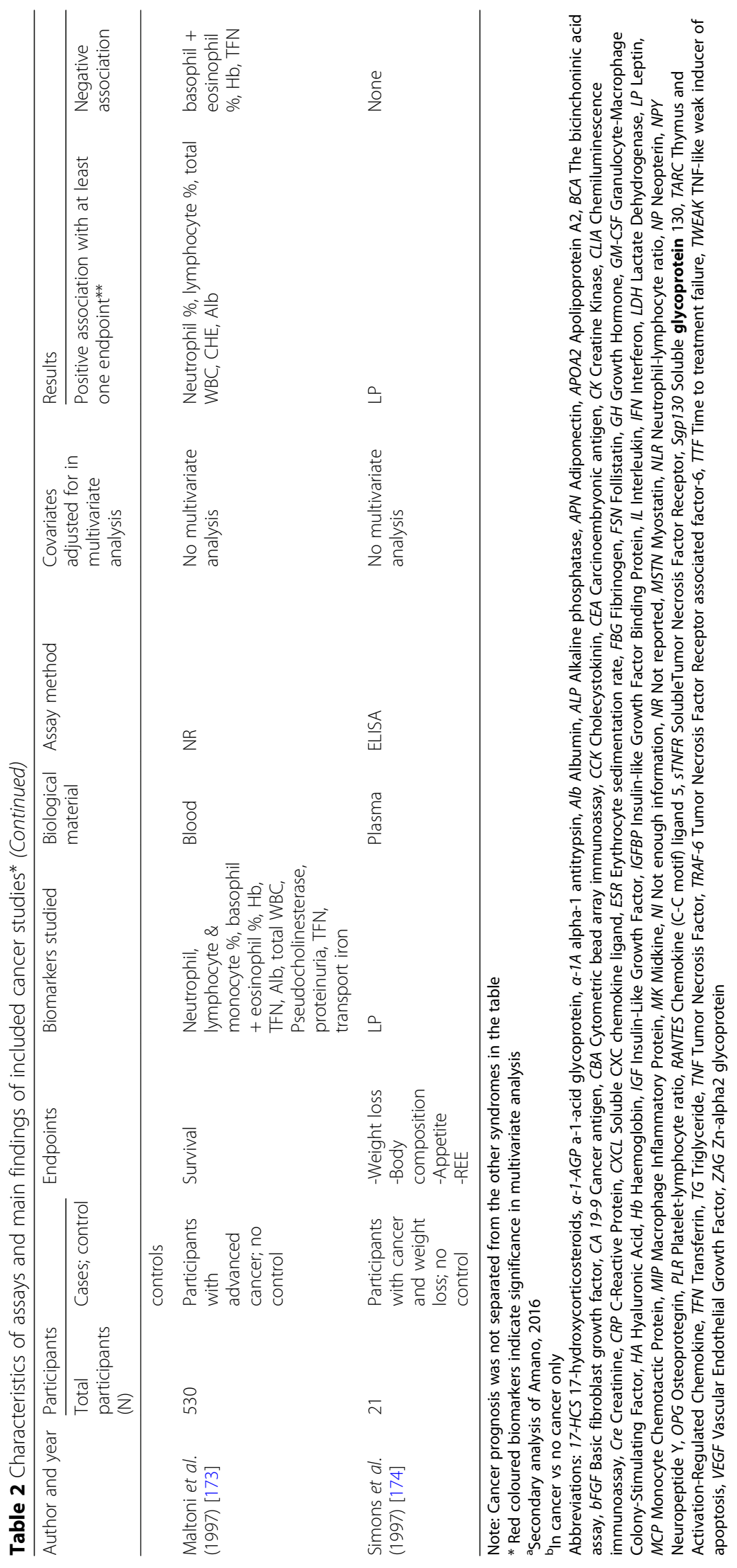




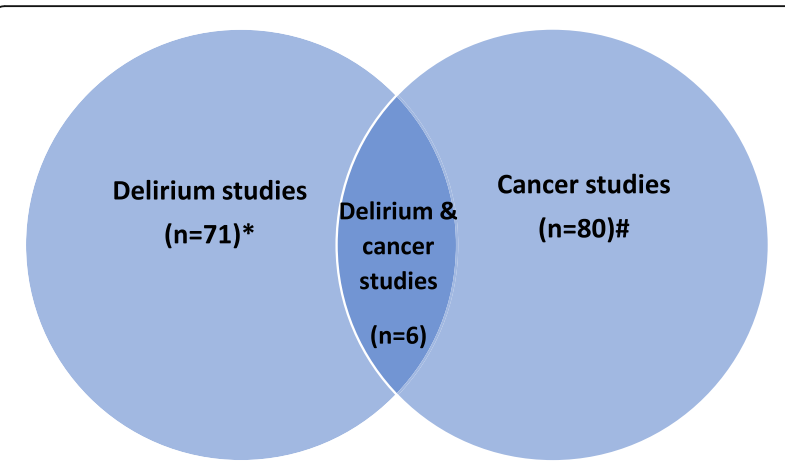

Fig. 2 Conceptual model illustrating the 'true overlap' of delirium and advanced cancer biomarker studies. ${ }^{*}$ Cancer as a comorbidity not measured/reported \# Delirium as a concurrent illness or comorbidity not measured/reported

participants who had delirium also had cancer, in another two, $26 \%$ and $27 \%$ of the delirium cohorts had cancer, and in the remaining study $14 \%$ of the delirium participants had cancer (Table 1). Although only six delirium studies reported co-existing cancer, there is still uncertainty as to how many participants in both groups of studies had both delirium and cancer. The two most common biomarkers in these six studies that reported a positive association with delirium were CRP $(n=3)$ and IL-6 $(n=3)$. It is unclear however whether these biomarkers were predominantly associated with delirium or the cancer, as three of the six studies grouped the delirium participants together, irrespective of their cancer comorbidity.

The quality assessment showed a large variability in the reporting of included studies. 150 (99\%) studies had a clear aim statement which included their outcome of interest. One study did not report a clear aims statement [175]. One hundred and nineteen studies (79\%) did not explicitly state the hypothesis; however, in most $(\mathrm{n}=94$; $62 \%)$ the hypothesis could be interpreted by the study aim. All 151 studies stated the participant population in detail. No study reported all elements of the assay methods in the REMARK checklist [23]. One hundred and thirty one studies (87\%) did not report whether assays were blinded to the study endpoint, however 59 $(45 \%)$ of those studies were objective assessments. Further, 14 studies $(9 \%)$ reported a power calculation to justify their sample size. Most $(\mathrm{n}=125 ; 83 \%)$ of studies defined all clinical endpoints examined. Ninety seven (64\%) studies undertook multivariate analysis, and of these 67 (69\%) described the multivariate model and the covariates included in the model, and 23 (23\%) explained the rationale for inclusion of the covariates in the models. (Additional files 4 and 5). Furthermore, 27 delirium studies (38\%) did not report the reason for admission. Of the 44 studies that did report the reason for admission, these were predominantly for surgery- elective and acute $(n=40)$. Most studies in the nonsurgical population did not report a reason for admission, with the exception of 4 studies where the medical condition of interest occurred on admission (e.g stroke). See additional files 4 and 5 for the complete quality assessments.

The methodological quality of the assay procedures only is depicted in Figure 3, with reporting of type of biological material mostly provided but much lower frequency of reporting for other critical descriptors.

\section{Discussion}

This is the first systematic review to our knowledge, to demonstrate the high degree of overlap in biomarkers in delirium, cancer prognosis and advanced cancer syndromes. This systematic review of 151 studies found that 41 biomarkers were independently investigated in studies of both delirium and prognosis/advanced cancer syndromes; with over half having a positive association in at least one study.

Biomarkers fall into three categories (though not mutually exclusive); those which present before disease onset that can help identify individuals who are most at risk of a particular disease (for example, genetic markers), those which are disease markers and as such, increase during disease progression and decrease after resolution, and thirdly, biomarker as an end-product of a disease for which levels are proportionate to 'damage' due to the disease [176]. The findings of this systematic review suggest that categorization along these lines is less understood in delirium. For example, there is evidence to show that conditions such as sepsis and hip fracture cause changes in inflammatory markers [177, 178], however, there is little evidence about whether delirium self-propagates. Some animal model data in delirium suggests that there might be a direct impact of inflammatory markers on brain dysfunction [179]. To our knowledge there was no published relationship between tumor markers and neurological brain dysfunction. Although clinical evidence suggests long term impacts on brain function, the exact pathophysiological mechanisms are poorly understood, and biomarkers to measure this are also unclear.

The issue of biomarker overlap between associated conditions has been researched in women with preeclampsia and polycystic ovary syndrome [180], however the overlap with respect to delirium and its associated conditions has not been well addressed. Of the 71 delirium studies, only five studies sought to determine the association with the participants' common primary condition in their analysis. Tomasi et al. (2017) found that biomarkers differed between patients in the three groups in those with sepsis alone and those who developed sepsis-associated encephalopathy, or delirium, 


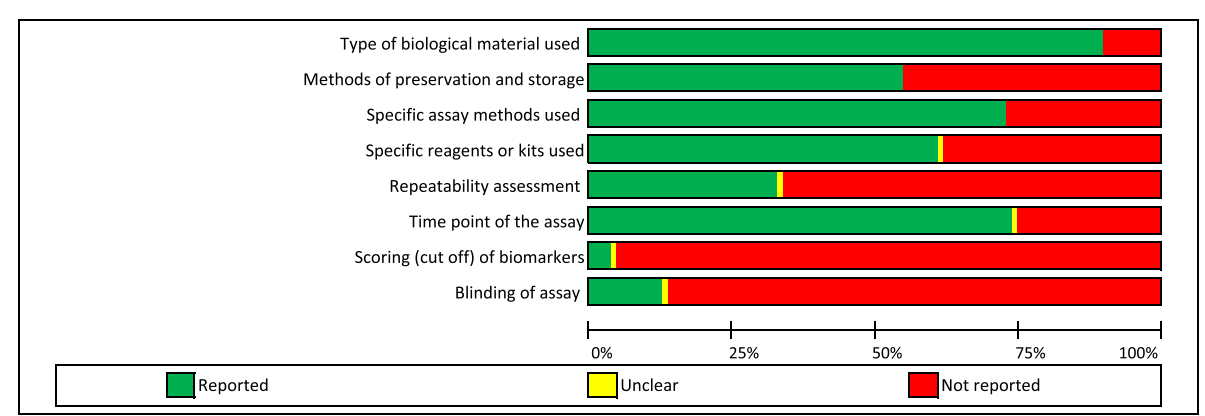

Fig. 3 Quality assessment graph of the assay procedures: review author's judgements about each assay domain of the REMARK checklist, presented as percentages across studies

suggesting different mechanisms of sepsis-associated encephalopathy, delirium in people with sepsis, and sepsis itself. Likewise, Pfister et al. (2008) found differences in CRP, s100 calcium binding protein B (s100B) and cortisol in patients with sepsis-associated delirium, compared to non-sepsis associated delirium. In two studies, delirium in stroke was examined [25, 92] but these studies did not identify differences in cortisol [92] or TNF- $\alpha$, IL- $1 \beta$, IL-18, Brain-derived neurotrophic factor (BDNF) and Neuron specific enolase (NSE) [25] between patients who developed delirium after stroke compared to those who did not develop delirium. Moreover, Sun et al. (2016) attempted to explore the overlap of biomarkers in delirium and dementia in patients with cancer, however, no multivariate analysis was undertaken, therefore results of this study are inconclusive.

Although the aim of this systematic review was to explore the overlap of biomarkers in delirium and advanced cancer syndromes, the findings highlighted a bigger problem in the methodology of delirium biomarker research. The quality assessment in this systematic review found that many of the included studies were of poor methodological quality, inadequately reported, or were influenced by potential confounding factors. A potential barrier to the complete understanding of delirium pathophysiology is the lack of guidelines for conducting and reporting delirium biomarker studies. Results from this review indicate that the absence of such guidelines has likely impeded the quality of individual studies and the overall quality of this critical field of delirium research. Reporting guidelines for delirium biomarker research are an essential step to improving methodological and reporting rigor, and will increase the potential for synthesis of future studies through metaanalyses.

Several studies have previously been performed to determine biomarkers associated with delirium, however potential confounding factors could be the underlying precipitants of delirium; ie risk factors (sepsis), or underlying conditions present (for example cancer or dementia). The top five most commonly studies biomarkers in this review were inflammatory biomarkers, namely, CRP, IL-6, TNF- $\alpha$, IL-10 and IL- 8 . The challenge with inflammatory markers is that they are nonspecific and the inflammatory pathways are similar to those implicated in other conditions such as sepsis and depression [181, 182]. Likewise, of the six delirium studies where there was concomitant cancer, it is very difficult to determine whether those biomarkers found were related to the cancer or the delirium itself, considering alterations in inflammatory pathways are implicated in both. Therefore, future delirium biomarker studies need to be prospectively evaluated and take into account and assess robustly other active co-morbidities such as cancer that could plausibly impact on the pathophysiological and/or biological findings. Similarly, future cancer biomarker studies must also take into account how delirium may clinically or biologically confound biomarker studies in cancer, considering the high prevalence of delirium in this population. Of the six delirium studies with cancer, three did not report the type of cancer, and of the remaining three studies, none were primary brain tumours or brain metastases. Understanding the spread of brain cancer is important in delirium studies, and is an important consideration for future delirium biomarker studies.

Majority of the studies in this review $(n=98 ; 65 \%)$ undertook a multivariate analysis, taking into account confounding variables. Where studies only undertook univariate analysis, it is uncertain whether any observed changes in biomarkers were related to the delirium itself, or whether these changes may have been lost when adjusted for confounding factors (such as prior cognitive impairment) in a multivariate analysis. Furthermore, there is likely to be a higher proportion of participants with both delirium and cancer in both groups of studies for which this clinical information was not assessed or that were not reported. Key methodological issues which need to be addressed in future delirium studies include 
adjusting for confounders such as age, gender, concurrent medication, comorbidities, prior cognitive impairment, frailty and other neurological conditions. These clinical covariates must also be clearly defined and justified. Assay procedures ought to be reported in detail, including a detailed protocol of the reagents/kits used, repeatability assessments, methods of preservation and storage, assay validity, sensitivity limits of the assay and a scoring and reporting protocol. The timing of the assay is crucial in delirium studies, and the fluctuating pathophysiological processes occurring during delirium, after delirium resolution, and in those who have not yet developed delirium, must be taken into consideration, and be separated in future studies. More standardised and detailed methods of delirium biomarker studies is a crucial step in carrying out future subgroup analyses within this cohort and improving the overall understanding of delirium pathophysiology.

Limitations are that only English language and published studies were included. It is possible that articles were missed; however, two reviewers independently screened all citations derived from a search of six relevant and diverse databases, and all reference lists of included articles were also searched. Another limitation of our study is the lack of a risk of bias tool for biomarker studies, therefore we used an adaptation of tumor marker reporting guidelines, the REMARK checklist [23]. Lastly, the heterogeneity of the data precluded the conduct of a meta-analysis, and precluded any firm conclusions about the biomarkers in delirium and cancer, thus, limiting the rigor of this review. Strengths of this review however, were that we undertook a systematic approach adhering to the PRISMA [15] and an extensive quality assessment of the included studies was undertaken.

\section{Conclusion}

This review found that there is large overlap in the biomarkers in delirium and in advanced cancer-related syndromes, although because of the heterogeneity of the studies firm conclusions about the true overlap of delirium and advanced cancer syndrome biomarkers was not possible. More robust conduct and reporting of delirium biomarker studies will help to better understand the pathophysiology of delirium in the context of co-existing pathophysiology. An improved understanding of the clinical and biological associations of delirium and advanced cancer syndromes in future prospective studies will provide and inform the directions of research into delirium in people with advanced cancer.

\section{Supplementary information}

Supplementary information accompanies this paper at https://doi.org/10. 1186/s12888-020-02584-2.
Additional file 1:. MEDLINE search strategies MEDLINE search strategies for delirium and cancer studies.

Additional file 2:. Participant characteristics- delirium studies Characteristics of participants in the included delirium studies.

Additional file 3:. Participant characteristics- cancer studies Characteristics of participants in the included cancer studies.

Additional file 4:. Quality assessment of included delirium studies using the REMARK checklist The quality assessment for all included delirium studies.

Additional file 5:. Quality assessment of included cancer studies using the REMARK checklist The quality assessment for all included cancer studies.

Additional file 6:. PRISMA checklist.

\section{Abbreviations}

BDNF: Brain-derived neurotrophic factor; CRP: C-reactive protein;

CSF: Cerebrospinal fluid; ELISA: Enzyme-linked immunosorbent assay; IL: Interleukin; NSE: Neuron specific enolase; S100B: S100B calcium binding protein B; TNF: Tumor necrosis factor

\section{Acknowledgements}

Not applicable.

Ethics approval and consent to participant

Not applicable.

\section{Authors' contributions}

IAD undertook the literature search, identified potential articles, extracted data, interpreted results, performed a quality assessment, drafted and revised all versions of the manuscript. MA and AH contributed to study selection and screening, interpreting results, revised manuscript drafts and supervised the study. All authors (IAD, AH, MA and GC) contributed to the interpretation of results, manuscript preparation and read and approved the final

manuscript.

\section{Funding}

None.

Availability of data and materials

All data generated or analysed in this systematic review are included within this published article and its additional files.

\section{Consent for publication}

Not applicable.

\section{Competing interests}

The authors declare that they have no competing interests.

\section{Author details}

${ }^{1}$ University of Technology Sydney, Faculty of Health, IMPACCT -Improving Palliative, Aged and Chronic Care through Clinical Research and Translation, Sydney, NSW, Australia. ${ }^{2}$ Prince of Wales Clinical School, University of New South Wales, Sydney, NSW, Australia. ${ }^{3}$ Department of Geriatric Medicine, Prince of Wales Hospital, Sydney, NSW, Australia. ${ }^{4}$ South West Sydney Clinical School, University of New South Wales, Liverpool, New South Wales, Australia. ${ }^{5}$ Clinical Trials, Ingham Institute of Applied Medical Research, Liverpool, New South Wales, Australia.

Received: 31 July 2019 Accepted: 5 April 2020

Published online: 22 April 2020

\section{References}

1. Hosie A, Davidson P, Agar M, Sanderson C, Phillips J. Delirium prevalence, incidence, and implications for screening in specialist palliative care inpatient settings: a systematic review. Palliat Med. 2013;27(6):486-98.

2. Davis DH, Skelly DT, Murray C, Hennessy E, Bowen J, Norton S, et al. Worsening cognitive impairment and neurodegenerative pathology progressively increase risk for delirium. Am J Geriatr Psychiatry. 2015;23(4): 403-15. 
3. Inouye SK, Westendorp RG, Saczynski JS. Delirium in elderly people. Lancet. 2014;383(9920):911-22

4. American Psychiatric Association. Diagnostic and statistical manual of mental disorders, fifth edition (DSM-5). Arlington: American Psychiatric Publisher; 2013.

5. National Clinical Guideline Centre for Acute and Chronic Conditions Delirium: diagnosis, prevention and management: NICE clinical guideline 103; 2010. Available from: https://www.nice.org.uk/guidance/cg103.

6. Neefjes EC, van der Vorst MJ, Verdegaal BA, Beekman AT, Berkhof J, Verheul HM. Identification of patients with cancer with a high risk to develop delirium. Cancer Med. 2017;6(8):1861-70.

7. Uchida M, Okuyama T, Ito Y, Nakaguchi T, Miyazaki M, Sakamoto M, et al. Prevalence, course and factors associated with delirium in elderly patients with advanced cancer: a longitudinal observational study. Jpn I Clin Oncol. 2015;45(10):934-40.

8. Grandahl MG, Nielsen SE, Koerner EA, Schultz HH, Arnfred SM. Prevalence of delirium among patients at a cancer ward: clinical risk factors and prediction by bedside cognitive tests. Nordic J Psychiatry. 2016;70(6):413-7.

9. Bush SH, Lawlor PG, Ryan K, Centeno C, Lucchesi M, Kanji S, et al. Delirium in adult cancer patients: ESMO clinical practice guidelines. Ann Oncol. 2018; 29(Supplement_4):iv143-iv65.

10. Maldonado JR. Delirium pathophysiology: an updated hypothesis of the etiology of acute brain failure. Int J Geriatr Psychiatry. 2017;33(11):1428-57.

11. Berr C. Cognitive impairment and oxidative stress in the elderly: results of epidemiological studies. Biofactors. 2000;13(1-4):205-9.

12. Haggstrom L, Nelson J, Wegner E, Caplan G. 2-18F-fluoro-2-deoxyglucose positron emission tomography in delirium. J Cereb Blood Flow Metab. 2017; 37(11):3556-67.

13. Caplan GA, Kvelde T, Lai C, Yap SL, Lin C, Hill MA. Cerebrospinal fluid in long-lasting delirium compared with Alzheimer's dementia. J Gerontol Series A-Med Sci. 2010;65(10):1130-6.

14. National Cancer Institute. NCI Dictionary of Cancer Terms [Available from: https://www.cancer.gov/publications/dictionaries/cancer-terms/?CdrlD=4561 8.

15. Liberati A, Altman DG, Tetzlaff J, Mulrow C, Gøtzsche PC, loannidis JP, et al. The PRISMA statement for reporting systematic reviews and meta-analyses of studies that evaluate health care interventions: explanation and elaboration. PLoS Med. 2009:6(7):e1000100.

16. Blum D, Omlin A, Fearon K, Baracos V, Radbruch L, Kaasa S, et al. Evolving classification systems for cancer cachexia: ready for clinical practice? Support Care Cancer. 2010;18(3):273-9.

17. Bower JE. Cancer-related fatigue-mechanisms, risk factors, and treatments. Clin Oncol. 2014;11(10):597.

18. International Association for the Study of Pain. IASP terminology Washington, USA; 2017. Available from: https://www.lasp-pain.org/ Education/Content.aspx?!temNumber=1698\&navltemNumber=576-Pain

19. Bray V, Dhillon H, Vardy J. Cancer-related cognitive impairment in adult cancer survivors: a review of the literature cancer forum; 2017. Available from: https://cancerforum.org.au/forum/2017/march/cancer-relatedcognitive-impairment-in-adult-cancer-survivors-a-review-of-the-literature/.

20. Dantzer R. Cytokine-induced sickness behaviour: a neuroimmune response to activation of innate immunity. Eur J Pharmacol. 2004;500(1-3):399-411.

21. Dantzer R. Cytokine-induced sickness behavior: where do we stand? Brain Behav Immun. 2001;15(1):7-24.

22. National Cancer Institute. Understanding cancer prognosis; 2018. Available from: https://www.cancer.gov/about-cancer/diagnosis-staging/prognosis.

23. Altman DG, McShane LM, Sauerbrei W, Taube SE. Reporting recommendations for tumor marker prognostic studies (REMARK): explanation and elaboration. BMC Med. 2012:10(1):51.

24. Egberts A, Mattace-Raso F. Increased neutrophil-lymphocyte ratio in delirium: a pilot study. Clin Interv Aging. 2017:12:1115.

25. Kozak HH, Uguz F, Kilinc I, Uca AU, Serhat Tokgoz O, Akpinar Z, et al. Delirium in patients with acute ischemic stroke admitted to the nonintensive stroke unit: incidence and association between clinical features and inflammatory markers. Neurol Neurochir Pol. 2017;51(1):38-44.

26. Tomasi CD, Vuolo F, Generoso J, Soares M, Barichello T, Quevedo J, et al. Biomarkers of delirium in a low-risk community-acquired pneumoniainduced sepsis. Mol Neurobiol. 2017;54(1):722-6.

27. Vasunilashorn SM, Dillon ST, Inouye SK, Ngo LH, Fong TG, Jones RN, et al. High C-reactive protein predicts delirium incidence, duration, and feature severity after major noncardiac surgery. J Am Geriatr Soc. 2017;65(8):e109.
28. Dillon ST, Vasunilashorn SM, Ngo L, Otu HH, Inouye SK, Jones RN, et al. Higher C-reactive protein levels predict postoperative delirium in older patients undergoing major elective surgery: a longitudinal nested casecontrol study. Biol Psychiatry. 2017;81(2):145-53.

29. Guo $Y$, Jia $P$, Zhang J, Wang $X$, Jiang H, Jiang W. Prevalence and risk factors of postoperative delirium in elderly hip fracture patients. J Int Med Res. 2016;44(2):317-27

30. Karlicic IS, Stasevic M, Jankovic S, Dejanovic SD, Milovanovic S. Markers of inflammation as risk predictors of lethal outcome in patients diagnosed with delirium. Vojnosanit Pregl. 2016;73(9):838-43.

31. Neerland BE, Hall RJ, Seljeflot I, Frihagen F, MacLullich AMJ, Ræder J, et al. Associations between delirium and preoperative cerebrospinal fluid Creactive protein, Interleukin-6, and Interleukin-6 receptor in individuals with acute hip fracture. J Am Geriatr Soc. 2016;64(7):1456-63.

32. Shen $\mathrm{H}$, Shao Y, Chen J, Guo J. Insulin-like growth factor-1, a potential predicative biomarker for postoperative delirium among elderly patients with open abdominal surgery. Curr Pharm Design. 2016;22(38):5879-83.

33. Sun L, Jia P, Zhang J, Zhang $X$, Zhang $Y$, Jiang $H$, et al. Production of inflammatory cytokines, cortisol, and Abeta1-40 in elderly oral cancer patients with postoperative delirium. Neuropsychiatr Dis Treat. 2016;12:2789-95.

34. Yen TE, Allen JC, Rivelli SK, Patterson SC, Metcalf MR, Flink BJ, et al. Association between serum IGF-I levels and postoperative delirium in elderly subjects undergoing elective knee arthroplasty. Sci Rep. 2016;6:20736.

35. Avila-Funes JA, Ledesma-Heyer JP, Navarrete-Reyes AP, Chavira-Ramirez R, Boeck-Quirasco L, Aguilar-Navarro S. Association between high serum estradiol levels and delirium among hospitalized elderly women. Rev Investig Clin. 2015;67(1):20-4.

36. Brum C, Stertz L, Borba E, Rumi D, Kapczinski F, Camozzato A. Association of serum brain-derived neurotrophic factor (BDNF) and tumor necrosis factoralpha (TNF-alpha) with diagnosis of delirium in oncology inpatients. Rev Bras Psiquiatr. 2015;37(3):197-202.

37. Egberts A, Wijnbeld EH, Fekkes D, van der Ploeg MA, Ziere G, Hooijkaas $H$, et al. Neopterin: a potential biomarker for delirium in elderly patients. Dement Geriatr Cogn Disord. 2015;39(1-2):116-24.

38. Foroughan M, Delbari A, Said SE, AkbariKamrani AA, Rashedi V, Zandi T. Risk factors and clinical aspects of delirium in elderly hospitalized patients in Iran. Aging Clin Exp Res. 2016;28(2):313-9.

39. Skrede K, Wyller TB, Watne LO, Seljeflot I, Juliebo V. Is there a role for monocyte chemoattractant protein-1 in delirium? Novel observations in elderly hip fracture patients. BMC Res Notes. 2015:8:186.

40. Vasunilashorn SM, Ngo L, Inouye SK, Libermann TA, Jones RN, Alsop DC, et al. Cytokines and postoperative delirium in older patients undergoing major elective surgery. J Gerontol Series A-Med Sci. 2015;70(10):1289-95.

41. Alexander SA, Ren D, Gunn SR, Kochanek PM, Tate J, Ikonomovic M, et al. Interleukin 6 and apolipoprotein E as predictors of acute brain dysfunction and survival in critical care patients. Am J Crit Care. 2014;23(1):49-57.

42. Baranyi A, Rothenhausler HB. The impact of soluble interleukin-2 receptor as a biomarker of delirium. [erratum appears in psychosomatics. 2014 Jul-Aug; 55(44):418-9]. Psychosomatics. 2014;55(1):51-60.

43. Cape E, Hall RJ, van Munster BC, de Vries A, Howie SE, Pearson A, et al. Cerebrospinal fluid markers of neuroinflammation in delirium: a role for interleukin-1 beta in delirium after hip fracture. J Psychosom Res. 2014;77(3): 219-25.

44. Capri M, Yani SL, Chattat R, Fortuna D, Bucci L, Lanzarini C, et al. Preoperative, high IL-6 blood level is a risk factor of postoperative delirium onset in old patients. Front Endocrinol. 2014;5:173 (SEP) (no pagination).

45. Chen XW, Shi JW, Yang PS, Wu ZQ. Preoperative plasma leptin levels predict delirium in elderly patients after hip fracture surgery. Peptides. 2014;57:31-5.

46. Hatta K, Kishi Y, Takeuchi T, Wada K, Odawara T, Usui C, et al. The predictive value of a change in natural killer cell activity for delirium. Prog NeuroPsychopharmacol Biol Psychiatry. 2014:48:26-31.

47. Kazmierski J, Banys A, Latek J, Bourke J, Jaszewski R, Sobow T, et al. Mild cognitive impairment with associated inflammatory and cortisol alterations as independent risk factor for postoperative delirium. Dement Geriatr Cogn Disord. 2014;38(1-2):65-78.

48. Ritchie CW, Newman TH, Leurent B, Sampson EL. The association between C-reactive protein and delirium in 710 acute elderly hospital admissions. Int Psychogeriatr. 2014;26(5):717-24

49. Ritter C, Tomasi CD, Dal-Pizzol F, Pinto BB, Dyson A, de Miranda AS, et al. Inflammation biomarkers and delirium in critically ill patients. Crit Care. 2014;18(3):R106 
50. Zhang Z, Pan L, Deng H, Ni H, Xu X. Prediction of delirium in critically ill patients with elevated C-reactive protein. J Crit Care. 2014;29(1):88-92.

51. Cerejeira J, Batista P, Nogueira V, Vaz-Serra A, Mukaetova-Ladinska EB. The stress response to surgery and postoperative delirium: evidence of hypothalamic-pituitary-adrenal axis hyperresponsiveness and decreased suppression of the GH/IGF-1 Axis. J Geriatr Psychiatry Neurol. 2013;26(3): 185-94

52. Colkesen Y, Giray S, Ozenli Y, Sezgin N, Coskun I. Relation of serum cortisol to delirium occurring after acute coronary syndromes. Am J Emerg Med. 2013:31(1):161-5.

53. Kazmierski J, Banys A, Latek J, Bourke J, Jaszewski R. Cortisol levels and neuropsychiatric diagnosis as markers of postoperative delirium: a prospective cohort study. Crit Care. 2013;17(2):R38.

54. Kazmierski J, Banys A, Latek J, Bourke J, Jaszewski R. Raised IL-2 and TNFalpha concentrations are associated with postoperative delirium in patients undergoing coronary-artery bypass graft surgery. Int Psychogeriatr. 2014; 26(5):845-55.

55. Liu P, Li YW, Wang XS, Zou X, Zhang DZ, Wang DX, et al. High serum interleukin-6 level is associated with increased risk of delirium in elderly patients after noncardiac surgery: a prospective cohort study. Chin Med J. 2013;126(19):3621-7.

56. Plaschke K, Hauth S, Jansen C, Bruckner T, Schramm C, Karck M, et al. The influence of preoperative serum anticholinergic activity and other risk factors for the development of postoperative cognitive dysfunction after cardiac surgery. J Thorac Cardiovasc Surg. 2013;145(3):805-11.

57. Skrobik Y, Leger C, Cossette M, Michaud V, Turgeon J. Factors predisposing to coma and delirium: fentanyl and midazolam exposure; CYP3A5, ABCB1, and ABCG2 genetic polymorphisms; and inflammatory factors. Crit Care Med. 2013;41(4):999-1008.

58. Westhoff D, Witlox J, Koenderman L, Kalisvaart KJ, de Jonghe JF, van Stijn MF, et al. Preoperative cerebrospinal fluid cytokine levels and the risk of postoperative delirium in elderly hip fracture patients. J Neuroinflammation. 2013;10:122.

59. Bakker RC, Osse RJ, Tulen JH, Kappetein AP, Bogers AJ. Preoperative and operative predictors of delirium after cardiac surgery in elderly patients. Eur J Cardiothorac Surg. 2012;41(3):544-9.

60. Baranyi A, Rothenhausler HB. The impact of intra- and postoperative albumin levels as a biomarker of delirium after cardiopulmonary bypass: results of an exploratory study. Psychiatry Res. 2012;200(2-3):957-63.

61. Cerejeira J, Nogueira V, Luis P, Vaz-Serra A, Mukaetova-Ladinska EB. The cholinergic system and inflammation: common pathways in delirium pathophysiology. J Am Geriatr Soc. 2012;60(4):669-75.

62. Girard TD, Ware LB, Bernard GR, Pandharipande PP, Thompson JL, Shintani AK, et al. Associations of markers of inflammation and coagulation with delirium during critical illness. Intensive Care Med. 2012;38(12):1965-73.

63. Osse RJ, Fekkes D, Tulen JH, Wierdsma Al, Bogers AJ, van der Mast RC, et al. High preoperative plasma neopterin predicts delirium after cardiac surgery in older adults. J Am Geriatr Soc. 2012;60(4):661-8.

64. Bisschop PH, de Rooij SE, Zwinderman AH, van Oosten HE, van Munster BC. Cortisol, insulin, and glucose and the risk of delirium in older adults with hip fracture. J Am Geriatr Soc. 2011;59(9):1692-6.

65. Holmes C, Cunningham C, Zotova E, Culliford D, Perry VH. Proinflammatory cytokines, sickness behavior, and Alzheimer disease. Neurology. 2011;77(3):212-8.

66. Lee HJ, Hwang DS, Wang SK, Chee IS, Baeg S, Kim JL. Early assessment of delirium in elderly patients after hip surgery. Psychiatry Investig. 2011;8(4):340-7.

67. McGrane S, Girard TD, Thompson JL, Shintani AK, Woodworth A, Ely EW, et al. Procalcitonin and C-reactive protein levels at admission as predictors of duration of acute brain dysfunction in critically ill patients. Crit Care. 2011; 15(2):R78.

68. Morandi A, Gunther ML, Pandharipande PP, Jackson JC, Thompson JL, Shintani AK, et al. Insulin-like growth factor-1 and delirium in critically ill mechanically ventilated patients: a preliminary investigation. Int Psychogeriatr. 2011;23(7):1175-81.

69. van den Boogaard M, Kox M, Quinn K, van Achterberg T, van der Hoeven J, Schoonhoven $\mathrm{L}$, et al. Biomarkers associated with delirium in critically ill patients and their relation with long-term subjective cognitive dysfunction; indications for different pathways governing delirium in inflamed and noninflamed patients. Crit Care. 2011;15:R297.

70. van den Boogaard M, van Swelm RPL, Russel FGM, Heemskerk S, van der Hoeven JG, Masereeuw R, et al. Urinary protein profiling in hyperactive delirium and non-delirium cardiac surgery ICU patients. Proteome Sci. 2011; 9:13 no pagination.
71. Burkhart C, Dell-Kuster S, Gamberini M, Moeckli A, Grapow M, Filipovic M, et al. Modifiable and nonmodifiable risk factors for postoperative delirium after cardiac surgery with cardiopulmonary bypass. J Cardiothorac Vasc Anesth. 2010;24(4):555-9 Available from: http://onlinelibrary.wiley.com/o/ cochrane/clcentral/articles/538/CN-00781538/frame.html.

72. Mu DL, Wang DX, Li LH, Shan GJ, Li J, Yu QJ, et al. High serum cortisol level is associated with increased risk of delirium after coronary artery bypass graft surgery: a prospective cohort study. Crit Care. 2010;14:6.

73. Pearson A, de Vries A, Middleton S, Gillies F, White T, Armstrong I, et al. Cerebrospinal fluid cortisol levels are higher in patients with delirium versus controls. BMC Res Notes. 2010;3(1):33.

74. Plaschke K, Fichtenkamm P, Schramm C, Hauth S, Martin E, Verch M, et al. Early postoperative delirium after open-heart cardiac surgery is associated with decreased bispectral EEG and increased cortisol and interleukin-6. Intensive Care Med. 2010;36(12):2081-9.

75. Tsuruta R, Nakahara T, Miyauchi T, Kutsuna S, Ogino Y, Yamamoto T, et al. Prevalence and associated factors for delirium in critically ill patients at a Japanese intensive care unit. Gen Hosp Psychiatry. 2010;32(6):607-11.

76. van Munster BC, Bisschop PH, Zwinderman AH, Korevaar JC, Endert E, Wiersinga WJ, et al. Cortisol, interleukins and S100B in delirium in the elderly. Brain Cogn. 2010;74(1):18-23.

77. Adamis D, Lunn M, Martin FC, Treloar A, Gregson N, Hamilton G, et al. Cytokines and IGF-I in delirious and non-delirious acutely ill older medical inpatients. Age Ageing. 2009;38(3):326-251.

78. van Munster BC, Korse CM, de Rooij SE, Bonfrer JM, Zwinderman AH, Korevaar JC. Markers of cerebral damage during delirium in elderly patients with hip fracture. BMC Neurol. 2009;9:21.

79. Lemstra AW, Kalisvaart KJ, Vreeswijk R, van Gool WA, Eikelenboom P. Preoperative inflammatory markers and the risk of postoperative delirium in elderly patients. Int J Geriatr Psychiatry. 2008;23(9):943-8.

80. Pfister D, Siegemund M, Dell-Kuster S, Smielewski P, Ruegg S, Strebel SP, et al. Cerebral perfusion in sepsis-associated delirium. Crit Care. 2008;12(3):R63.

81. Rudolph JL, Ramlawi B, Kuchel GA, McElhaney JE, Xie D, Sellke FW, et al. Chemokines are associated with delirium after cardiac surgery. J Gerontol Series A-Med Sci. 2008;63(2):184-9.

82. Van Munster BC, Korevaar JC, Zwinderman AH, Levi M, Wiersinga WJ, De Rooij SE. Time-course of cytokines during delirium in elderly patients with hip fractures. J Am Geriatr Soc. 2008;56(9):1704-9.

83. Adamis D, Treloar A, Martin FC, Gregson N, Hamilton G, Macdonald AJD. APOE and cytokines as biological markers for recovery of prevalent delirium in elderly medical inpatients. Int J Geriatr Psychiatry. 2007;22(7):688-94.

84. de Rooij SE, van Munster BC, Korevaar JC, Levi M. Cytokines and acute phase response in delirium. J Psychosom Res. 2007;62(5):521-5.

85. Plaschke K, Hill H, Engelhardt R, Thomas C, von Haken R, Scholz M, et al. EEG changes and serum anticholinergic activity measured in patients with delirium in the intensive care unit. Anaesthesia. 2007;62(12):1217-23.

86. White S, Calver BL, Newsway V, Wade R, Patel S, Bayer A, et al. Enzymes of drug metabolism during delirium. Age Ageing. 2005;34(6):603-8.

87. Wilson K, Broadhurst C, Diver M, Jackson M, Mottram P. Plasma insulin growth factor-1 and incident delirium in older people. Int J Geriatr Psychiatry. 2005;20(2):154-9.

88. Beloosesky Y, Grinblat J, Pirotsky A, Weiss A, Hendel D. Different C-reactive protein kinetics in post-operative hip-fractured geriatric patients with and without complications. Gerontology. 2004;50(4):216-22.

89. Robertsson B, Blennow K, Brane G, Edman A, Karlsson I, Wallin A, et al. Hyperactivity in the hypothalamic-pituitary-adrenal axis in demented patients with delirium. Int Clin Psychopharmacol. 2001;16(1):39-47.

90. van der Mast RC, van den Broek WW, Fekkes D, Pepplinkhuizen L, Habbema JD. Is delirium after cardiac surgery related to plasma amino acids and physical condition? J Neuropsychiatr Clin Neurosci. 2000;12(1):57-63.

91. van der Mast RC, van den Broek WW, Fekkes D, Pepplinkhuizen L, Habbema JDF. Incidence of and preoperative predictors for delirium after cardiac surgery. J Psychosom Res. 1999;46(5):479-83.

92. Gustafson $Y$, Olsson T, Asplund $K$, Hägg E. Acute confusional state (delirium) soon after stroke is associated with hypercortisolism. Cerebrovasc Dis. 1993;3(1):33-8.

93. Mclntosh TK, Bush HL, Yeston NS. Beta-endorphin, cortisol and postoperative delirium: a preliminary report. Psychoneuroendocrinology. 1985;10(3):303-13.

94. Amano K, Maeda I, Morita T, Baba M, Miura T, Hama T, et al. C-reactive protein, symptoms and activity of daily living in patients with advanced cancer receiving palliative care. J Cachexia Sarcopenia Muscle. 2017;8(3):457. 
95. Demiray G, DeGirmencioGlu S, Ugurlu E, Yaren A. Effects of serum leptin and resistin levels on cancer cachexia in patients with advanced-stage nonsmall cell lung cancer. Clin Med Insights. 2017;11:1 (no pagination) (1179554917690144).

96. Fogelman DR, Morris J, Xiao L, Hassan M, Vadhan S, Overman M, et al. A predictive model of inflammatory markers and patient-reported symptoms for cachexia in newly diagnosed pancreatic cancer patients. Support Care Cancer. 2017;25(6):1809-17.

97. Luo Y, Kim HS, Kim M, Lee M, Song YS. Elevated plasma fibrinogen levels and prognosis of epithelial ovarian cancer: a cohort study and metaanalysis. J Gynecol Oncol. 2017;28:3.

98. Paulsen O, Laird B, Aass N, Lea T, Fayers P, Kaasa S, et al. The relationship between pro-inflammatory cytokines and pain, appetite and fatigue in patients with advanced cancer. PLoS One. 2017;12(5):e0177620 no pagination.

99. Amano K, Maeda I, Morita T, Miura T, Inoue S, Ikenaga M, et al. Clinical implications of C-reactive protein as a prognostic marker in advanced cancer patients in palliative settings. Eur J Cancer. 2016;51:S207.

100. Bye A, Wesseltoft-Rao N, Iversen PO, Skjegstad G, Holven KB, Ulven S, et al. Alterations in inflammatory biomarkers and energy intake in cancer cachexia: a prospective study in patients with inoperable pancreatic cancer. Med Oncol. 2016;33(6):54.

101. Mitsunaga S, Ikeda M, Shimizu S, Ohno I, Takahashi H, Okuyama H, et al. Creactive protein level is an indicator of the aggressiveness of advanced pancreatic cancer. Pancreas. 2016;45(1):110-6.

102. Morgado PC, Giorlando A, Castro M, Navigante A. Relationship between weight loss and parameters of skeletal muscle function in patients with advanced cancer and fatigue. Support Care Cancer. 2016;24(9):3961-6.

103. Rodrigues AR, Trufelli DC, Fonseca F, de Paula LC. Giglio ad. Fatigue in patients with advanced terminal cancer correlates with inflammation, poor quality of life and sleep, and anxiety/depression. Am J Hosp Palliat Med. 2016;33(10):942-7.

104. Srdic D, Plestina S, Sverko-Peternac A, Nikolac N, Simundic AM, Samarzija M. Cancer cachexia, sarcopenia and biochemical markers in patients with advanced non-small cell lung cancer-chemotherapy toxicity and prognostic value. Support Care Cancer. 2016;24(11):4495-502.

105. Wu Y, Li C, Zhao J, Yang L, Liu F, Zheng H, et al. Neutrophil-to-lymphocyte and platelet-to-lymphocyte ratios predict chemotherapy outcomes and prognosis in patients with colorectal cancer and synchronous liver metastasis. World J Surg Oncol. 2016;14(1):289.

106. Bilir C, Engin H, Can M, Temi YB, Demirtas D. The prognostic role of inflammation and hormones in patients with metastatic cancer with cachexia. Med Oncol. 2015:32(3):56.

107. Miura T, Mitsunaga S, Ikeda M, Shimizu S, Ohno I, Takahashi H, et al. Characterization of patients with advanced pancreatic cancer and high serum interleukin-6 levels. Pancreas. 2015;44(5):756-63.

108. Miura T, Matsumoto $Y$, Hama T, Amano K, Tei Y, Kikuchi A, et al. Glasgow prognostic score predicts prognosis for cancer patients in palliative settings: a subanalysis of the Japan-prognostic assessment tools validation (J-ProVal) study. Support Care Cancer. 2015;23(11):3149-56.

109. Barrera L, Montes-Servín E, Barrera A, Ramirez-Tirado L, Salinas-Parra F, Banales-Mendez J, et al. Cytokine profile determined by data-mining analysis set into clusters of non-small-cell lung cancer patients according to prognosis. Ann Oncol. 2014;26(2):428-35.

110. Blakely AM, Heffernan DS, McPhillips J, Cioffi WG, Miner TJ. Elevated Creactive protein as a predictor of patient outcomes following palliative surgery. J Surg Oncol. 2014;110(6):651-5.

111. Fujiwara Y, Kobayashi T, Chayahara N, Imamura Y, Toyoda M, Kiyota N, et al. Metabolomics evaluation of serum markers for cachexia and their intra-day variation in patients with advanced pancreatic cancer. PLoS One. 2014;9(11): e113259.

112. Lindenmann J, Neubock N, Smolle J, Maier A, Smolle-Juttner FM. The influence of elevated levels of C-reactive protein and hypoalbuminaemia on survival in patients with advanced inoperable oesophageal cancer undergoing palliative treatment. Eur Surg. 2014;46:S57.

113. Mondello P, Lacquaniti A, Mondello S, Bolignano D, Pitini V, Aloisi C, et al. Emerging markers of cachexia predict survival in cancer patients. BMC Cancer. 2014:14(1):828.

114. Moriwaki T, Ishige K, Araki M, Yoshida S, Nishi M, Sato M, et al. Glasgow prognostic score predicts poor prognosis among advanced biliary tract cancer patients with good performance status. Med Oncol. 2014;31(11):287.
115. Szkandera J, Stotz M, Absenger G, Stojakovic T, Samonigg H, Kornprat $P$, et al. Validation of C-reactive protein levels as a prognostic indicator for survival in a large cohort of pancreatic cancer patients. Br J Cancer. 2014; 110(1):183.

116. Zhang SY, Zeng D, Peng YH, Yang YX, Zhuang XW, Li ZT, et al. Cancerrelated fatigue and chemotherapy-associated adverse effects: correlation with TNF-alpha, IL-1 and 17-hydroxycorticosteroids. Future Oncol. 2014; 10(9):1619-26.

117. Jafri SH, Shi R, Mills G. Advance lung cancer inflammation index (ALI) at diagnosis is a prognostic marker in patients with metastatic non-small cell lung cancer (NSCLC): a retrospective review. BMC Cancer. 2013;13(1):158.

118. Laird BJ, McMillan DC, Fayers P, Fearon K, Kaasa S, Fallon MT, et al. The systemic inflammatory response and its relationship to pain and other symptoms in advanced cancer. Oncologist. 2013;18(9):1050-5.

119. Laird BJ, Kaasa S, McMillan DC, Fallon MT, Hjermstad MJ, Fayers $P$, et al. Prognostic factors in patients with advanced cancer: a comparison of clinicopathological factors and the development of an inflammation-based prognostic system. Clin Cancer Res. 2013;19(19):5456-64.

120. Paiva CE, Paiva BSR. Prevalence, predictors, and prognostic impact of fatigue among Brazilian outpatients with advanced cancers. Support Care Cancer. 2013;21(4):1053-60.

121. Suh SY, Choi YS, Yeom CH, Kwak SM, Yoon HM, Kim DG, et al. Interleukin-6 but not tumour necrosis factor-alpha predicts survival in patients with advanced cancer. Support Care Cancer. 2013;21(11):3071-7.

122. de Raaf P, Sleijfer S, Lamers C, Jager A, Gratama J, van der Rijt C. The association between inflammation and fatigue dimensions in advanced cancer patients and cancer survivors. Palliat Med. 2012;26(4):449-50.

123. Gioulbasanis I, Patrikidou A, Kitikidou K, Papadimitriou K, Vlachostergios PJ Tsatsanis C, et al. Baseline plasma levels of Interleukin-8 in stage IV nonsmall-cell lung cancer patients: relationship with nutritional status and prognosis. Nutr Cancer. 2012;64(1):41-7

124. Gulen ST, Karadag F, Karul AB, Kilicarslan N, Ceylan E, Kuman NK, et al. Adipokines and systemic inflammation in weight-losing lung cancer patients. Lung. 2012;190(3):327-32.

125. Heitzer E, Sandner-Kiesling A, Schippinger W, Stohscheer I, Osprian I, Bitsche S, et al. IL-7, IL-18, MCP-1, MIP1-beta, and OPG as biomarkers for pain treatment response in patients with cancer. Pain Physician. 2012;15(6):499510.

126. Minton O, Strasser F, Radbruch L, Stone P. Identification of factors associated with fatigue in advanced cancer: a subset analysis of the European palliative care research collaborative computerized symptom assessment data set. J Pain Symptom Manag. 2012;43(2):226-35.

127. Partridge M, Fallon M, Bray C, McMillan D, Brown D, Laird B. Prognostication in advanced cancer: a study examining an inflammation-based score. J Pain Symptom Manag. 2012:44(2):161-7.

128. Pond GR, Armstrong AJ, Wood BA, Leopold L, Galsky MD, Sonpavde G. Ability of C-reactive protein to complement multiple prognostic classifiers in men with metastatic castration resistant prostate cancer receiving docetaxel-based chemotherapy. BJU Int. 2012;110:11b.

129. Wang D-s, Luo H-y, M-z Q, Wang Z-q, D-s Z, Wang F-h, et al. Comparison of the prognostic values of various inflammation based factors in patients with pancreatic cancer. Med Oncol. 2012;29(5):3092-100.

130. Aydin Y, Kaplan I, Gundogdu B, Albayrak B, Turkyilmaz A, Eroglu A. Prognostic importance of serum CRP, prealbumin, and transferrin levels in patients with advanced stage esophageal cancer. Turk Gogus Kalp Damar Cerrahisi Derg. 2011;19(3):384-90

131. Dev R, Hui D, Dalal S, Nooruddin Zl, Yennurajalingam S, Del Fabbro E, et al. Association between serum cortisol and testosterone levels, opioid therapy, and symptom distress in patients with advanced cancer. J Pain Symptom Manag. 2011;41(4):788-95.

132. Gioulbasanis I, Georgoulias P, Vlachostergios PJ, Baracos V, Ghosh S, Giannousi Z, et al. Mini nutritional assessment (MNA) and biochemical markers of cachexia in metastatic lung cancer patients: interrelations and associations with prognosis. Lung Cancer. 2011;74(3):516-20.

133. Hwang J-E, Kim H-N, Kim D-E, Choi H-J, Jung S-H, Shim H-J, et al. Prognostic significance of a systemic inflammatory response in patients receiving firstline palliative chemotherapy for recurred or metastatic gastric cancer. BMC Cancer. 2011:11(1):489.

134. Kwak SM, Choi YS, Yoon HM, Kim DG, Song SH, Lee YJ, et al. The relationship between interleukin-6, tumor necrosis factor- $a$, and fatigue in terminally ill cancer patients. Palliat Med. 2012;26(3):275-82. 
135. Lee JS, Kwon OY, Choi HS, Hong HP, Ko YG. Serum C-reactive protein level is a predictive factor for 14-day mortality of patients with advanced cancer who present to the emergency department with acute symptoms. Acad Emerg Med. 2011;18(4):440-2

136. Scheede-Bergdahl C, Watt HL, Trutschnigg B, Kilgour RD, Haggarty A, Lucar $E$, et al. Is IL-6 the best pro-inflammatory biomarker of clinical outcomes of cancer cachexia? Clin Nutr. 2012;31(1):85-8.

137. Vlachostergios P, Gioulbasanis I, Kamposioras K, Georgoulias P, Baracos V, Ghosh S, et al. Baseline insulin-like growth factor-l plasma levels, systemic inflammation, weight loss and clinical outcome in metastatic non-small cell lung cancer patients. Oncol. 2011;81(2):113-8.

138. Diakowska D, Krzystek-Korpacka M, Markocka-Maczka K, Diakowski W, Matusiewicz M, Grabowski K. Circulating leptin and inflammatory response in esophageal cancer, esophageal cancer-related cachexia-anorexia syndrome (CAS) and non-malignant CAS of the alimentary tract. Cytokine. 2010;51(2):132-7.

139. Meek CL, Wallace AM, Forrest LM, McMillan DC. The relationship between the insulin-like growth factor-1 axis, weight loss, an inflammation-based score and survival in patients with inoperable non-small cell lung cancer. Clin Nutr. 2010:29(2):206-9.

140. Ishizuka M, Nagata H, Takagi K, Kubota K. Influence of inflammation-based prognostic score on mortality of patients undergoing chemotherapy for far advanced or recurrent unresectable colorectal cancer. Ann Surg. 2009; 250(2):268-72.

141. Karapanagiotou EM, Polyzos A, Dilana KD, Gratsias I, Boura P, Gkiozos I, et al. Increased serum levels of ghrelin at diagnosis mediate body weight loss in non-small cell lung cancer (NSCLC) patients. Lung Cancer. 2009;66(3):393-8.

142. Paddison JS, Temel JS, Fricchione GL, Pirl WF. Using the differential from complete blood counts as a biomarker of fatigue in advanced non-small-cell lung cancer: an exploratory analysis. Palliat Support Care. 2009;7(2):213-7.

143. Takahashi M, Terashima M, Takagane A, Oyama K, Fujiwara H, Wakabayashi G. Ghrelin and leptin levels in cachectic patients with cancer of the digestive organs. Int J Clin Oncol. 2009;14(4):315-20.

144. Inagaki M, Isono M, Okuyama T, Sugawara Y, Akechi T, Akizuki N, et al. Plasma interleukin- 6 and fatigue in terminally ill cancer patients. J Pain Symptom Manag. 2008;35(2):153-61.

145. Karapanagiotou EM, Tsochatzis EA, Dilana KD, Tourkantonis I, Gratsias I, Syrigos KN. The significance of leptin, adiponectin, and resistin serum levels in non-small cell lung cancer (NSCLC). Lung Cancer. 2008;61(3):391-7.

146. Sharma R, Zucknick M, London R, Kacevska M, Liddle C, Clarke SJ. Systemic inflammatory response predicts prognosis in patients with advanced-stage colorectal cancer. Clin Colorectal Cancer. 2008;7(5):331-7.

147. Weryńska B, Kosacka M, Gołecki M, Jankowska R. Leptin serum levels in cachectic and non-cachectic lung cancer patients. Adv Respi Med. 2009; 77(6):500-6.

148. Ravasco P, Monteiro-Grillo I, Camilo M. How relevant are cytokines in colorectal cancer wasting? Cancer J. 2007;13(6):392-8.

149. Richey LM, George JR, Couch ME, Kanapkey BK, Yin X, Cannon T, et al. Defining cancer cachexia in head and neck squamous cell carcinoma. Clin Cancer Res. 2007;13(22):6561-7.

150. Suh S-Y, Ahn H-Y. A prospective study on C-reactive protein as a prognostic factor for survival time of terminally ill cancer patients. Support Care Cancer. 2007;15(6):613

151. Al Murri A, Bartlett J, Canney P, Doughty J, Wilson C, McMillan D. Evaluation of an inflammation-based prognostic score (GPS) in patients with metastatic breast cancer. Br J Cancer. 2006:94(2):227.

152. Kayacan O, Karnak D, Beder S, Güllü E, Tutkak H, Senler FC, et al. Impact of TNF-[alpha] and IL-6 levels on development of cachexia in newly diagnosed NSCLC patients. Am J Clin Oncol. 2006;29(4):328-35.

153. Ramsey S, Lamb GW, Aitchison M, Graham J, McMillan DC. Evaluation of an inflammation-based prognostic score in patients with metastatic renal cancer. Cancer. 2007;109(2):205-12.

154. Di Nisio M, Niers TM, Reitsma PH, Buller HR. Plasma cytokine and P-selectin levels in advanced malignancy: prognostic value and impact of lowmolecular weight heparin administration. Cancer. 2005;104(10):2275-81.

155. Rich T, Innominato PF, Boerner J, Mormont MC, lacobelli S, Baron B, et al. Elevated serum cytokines correlated with altered behavior, serum cortisol rhythm, and dampened 24-hour rest-activity patterns in patients with metastatic colorectal cancer. Clin Cancer Res. 2005;11(5):1757-64.

156. Bolukbas FF, Kilic H, Bolukbas C, Gumus M, Horoz M, Turhal NS, et al. Serum leptin concentration and advanced gastrointestinal cancers: a case controlled study. BMC Cancer. 2004;4(1):29.
157. De Vita F, Romano C, Orditura M, Galizia G, Martinelli E, Lieto E, et al. Interleukin-6 serum level correlates with survival in advanced gastrointestinal cancer patients but is not an independent prognostic indicator. J Interf Cytokine Res. 2001;21(1):45-52.

158. Dülger H, Alici S, ŞekeroǦlu M, Erkog R, Özbek H, Noyan T, et al. Serum levels of leptin and proinflammatory cytokines in patients with gastrointestinal cancer. Int J Clin Pract. 2004;58(6):545-9.

159. Elahi MM, McMillan DC, McArdle CS, Angerson WJ, Sattar N. Score based on hypoalbuminemia and elevated C-reactive protein predicts survival in patients with advanced gastrointestinal cancer. Nutr Cancer. 2004;48(2):171-

160. Jamieson NB, Brown DJ, Wallace AM, McMillan DC. Adiponectin and the systemic inflammatory response in weight-losing patients with non-small cell lung cancer. Cytokine. 2004;27(2-3):90-2.

161. Songur N, Kuru B, Kalkan F, Ozdilekcan C, Cakmak H, Hizel N. Serum interleukin-6 levels correlate with malnutrition and survival in patients with advanced non-small cell lung cancer. Tumori. 2004;90(2):196-200.

162. Scott HR, McMillan DC, Brown DJ, Forrest LM, McArdle CS, Milroy R. A prospective study of the impact of weight loss and the systemic inflammatory response on quality of life in patients with inoperable nonsmall cell lung cancer. Lung Cancer. 2003:40(3):295-9.

163. Alemán MR, Santolaria F, Batista N, Marı J, González-Reimers E, Milena A, et al. Leptin role in advanced lung cancer. A mediator of the acute phase response or a marker of the status of nutrition? Cytokine. 2002;19(1):21-6.

164. Orditura M, De Vita F, Catalano G, Infusino S, Lieto E, Martinelli E, et al. Elevated serum levels of interleukin-8 in advanced non-small cell lung cancer patients: relationship with prognosis. J Interf Cytokine Res. 2002; 22(11):1129-35.

165. Scott H, McMillan D, Forrest L, Brown D, McArdle C, Milroy R. The systemic inflammatory response, weight loss, performance status and survival in patients with inoperable non-small cell lung cancer. Br J Cancer. 2002;87(3):264.

166. Jatoi A, Loprinzi CL, Sloan JA, Klee GG, Windschitl HE. Neuropeptide Y, leptin, and cholecystokinin 8 in patients with advanced cancer and anorexia - a north Central cancer treatment group exploratory investigation. Cancer. 2001;92(3):629-33

167. Mantovani G, Maccio A, Madeddu C, Mura L, Massa E, Mudu M, et al. Serum values of proinflammatory cytokines are inversely correlated with serum leptin levels in patients with advanced stage cancer at different sites. J Mol Med. 2001;79(7):406-14

168. Mantovani G, Maccio A, Mura L, Massa E, Mudu MC, Mulas C, et al. Serum levels of leptin and proinflammatory cytokines in patients with advancedstage cancer at different sites. J Mol Med. 2000;78(10):554-61.

169. Nenova K, Kovatchev D. TNF-A levels in cachectic cancer patients. Arch Hellenic Med. 2000;17(6):619-22.

170. O'Gorman P, McMillan DC, McArdle CS. Longitudinal study of weight, appetite, performance status, and inflammation in advanced gastrointestinal cancer. Nutr Cancer. 1999:35(2):127-9.

171. Okada S, Okusaka T, Ishii H, Kyogoku A, Yoshimori M, Kajimura N, et al. Elevated serum interleukin-6 levels in patients with pancreatic cancer. Jpn J Clin Oncol. 1998;28(1):12-5

172. Wallace AM, Kelly A, Sattar N, McArdle CS, McMillan DC. Circulating concentrations of "free" leptin in relation to fat mass and appetite in gastrointestinal cancer patients. Nutr Cancer. 2002:44(2):157-60.

173. Maltoni M, Marco P, Oriana N, Mauro M, Monica I, Gramazio A, et al. Biological indices predictive of survival in 519 Italian terminally ill cancer patients. J Pain Symptom Manag. 1997;13:1.

174. Simons J, Schols A, Campfield L, Wouters E, Saris W. Plasma concentration of total leptin and human lung-cancer-associated cachexia. Clin Sci. 1997; 93(3):273-7.

175. Wallace A, Sattar N, McMillan D. Effect of weight loss and the inflammatory response on leptin concentrations in gastrointestinal cancer patients. Clin Cancer Res. 1998:4(12):2977-9.

176. Marcantonio ER, Rudolph JL, Culley D, Crosby G, Alsop D, Inouye SK. Serum biomarkers for delirium. J Gerontol Series A-Med Sci. 2006:61(12):1281-6.

177. Kellum JA, Kong L, Fink MP, Weissfeld LA, Yealy DM, Pinsky MR, et al. Understanding the inflammatory cytokine response in pneumonia and sepsis: results of the genetic and inflammatory markers of sepsis (GenIMS) study. Arch Intern Med. 2007;167(15):1655-63.

178. Saribal D, Hocaoglu-Emre F, Erdogan S, Bahtiyar N, Okur SC, Mert M. Inflammatory cytokines $\mathrm{L}-6$ and TNF- $a$ in patients with hip fracture. Osteoporos Int. 2019;30(5):1025-31. 
179. Hennessy E, Gormley S, Lopez-Rodriguez AB, Murray C, Murray C, Cunningham C. Systemic TNF-a produces acute cognitive dysfunction and exaggerated sickness behavior when superimposed upon progressive neurodegeneration. Brain Behav Immun. 2017;59:233-44.

180. Khan GH, Galazis N, Docheva N, Layfield R, Atiomo W. Overlap of proteomics biomarkers between women with pre-eclampsia and PCOS: a systematic review and biomarker database integration. Hum Reprod. 2014; 30(1):133-48.

181. Strawbridge R, Young AH, Cleare AJ. Biomarkers for depression: recent insights, current challenges and future prospects. Neuropsychiatr Dis Treat. 2017;13:1245.

182. Cho S-Y, Choi J-H. Biomarkers of sepsis. Infect Chemother. 2014;46(1):1-12.

\section{Publisher's Note}

Springer Nature remains neutral with regard to jurisdictional claims in published maps and institutional affiliations.

Ready to submit your research? Choose BMC and benefit from:

- fast, convenient online submission

- thorough peer review by experienced researchers in your field

- rapid publication on acceptance

- support for research data, including large and complex data types

- gold Open Access which fosters wider collaboration and increased citations

- maximum visibility for your research: over $100 \mathrm{M}$ website views per year

At BMC, research is always in progress.

Learn more biomedcentral.com/submissions 